NBER WORKING PAPER SERIES

\title{
QUALITY OF LIFE, FIRM PRODUCTIVITY, AND THE VALUE OF AMENITIES ACROSS CANADIAN CITIES
}

\author{
David Albouy \\ Fernando Leibovici \\ Casey Warman \\ Working Paper 18103 \\ http://www.nber.org/papers/w18103
}

\author{
NATIONAL BUREAU OF ECONOMIC RESEARCH \\ 1050 Massachusetts Avenue \\ Cambridge, MA 02138
}

May 2012

Please contact at the Department of Economics, 611 Tappan St., Ann Arbor, MI 48109-1220 or albouy@umich.edu. We would like to thank Kevin Milligan, James Milway, Daniel Parent, and participants of seminars at McGill University, Queens University, Simon Fraser University, the University of British Columbia, and the University of Victoria and attendees at the 2009 Canadian Economics Association and Western Economics Association Annual Meetings for their help, input, and advice. All mistakes are our own. The authors gratefully acknowledge the financial assistance provided by the Social Sciences and Humanities Research Council of Canada (SSHRC). While the research and analysis are based on data from Statistics Canada, this paper represents the views of the authors and does not necessarily reflect the opinions of Statistics Canada, nor does it necessarily reflect the views of the National Bureau of Economic Research.

NBER working papers are circulated for discussion and comment purposes. They have not been peerreviewed or been subject to the review by the NBER Board of Directors that accompanies official NBER publications.

(C) 2012 by David Albouy, Fernando Leibovici, and Casey Warman. All rights reserved. Short sections of text, not to exceed two paragraphs, may be quoted without explicit permission provided that full credit, including $\odot$ notice, is given to the source. 
Quality of Life, Firm Productivity, and the Value of Amenities across Canadian Cities

David Albouy, Fernando Leibovici, and Casey Warman

NBER Working Paper No. 18103

May 2012

JEL No. J31,J61,Q51,R1

\begin{abstract}
$\underline{\text { ABSTRACT }}$
We present hedonic general-equilibrium estimates of quality-of-life and productivity differences across Canada's metropolitan areas. These are based off of the estimated willingness-to-pay of heterogeneous households and firms to locate in various cities, which differ in their wage levels, housing costs, and land values. Using 2006 Canadian Census data, our metropolitan quality-of-life estimates are somewhat consistent with popular rankings, but find Canadians care more about climate and culture. Quality-of-life is highest in Victoria for Anglophones, Montreal for Francophones, and Vancouver for Allophones, and lowest in more remote cities. Toronto is Canada's most productive city; Vancouver is the overall most valuable city.
\end{abstract}

\author{
David Albouy \\ Department of Economics \\ University of Michigan \\ 611 Tappan Street \\ 351C Lorch Hall \\ Ann Arbor, MI 48109-1220 \\ and NBER \\ albouy@umich.edu \\ Fernando Leibovici \\ Economics Department \\ New York University \\ 19 W. 4th Street, 6FL \\ New York, NY 10012 \\ fml234@nyu.edu
}

Casey Warman

Department of Economics

Dunning Hall, Room 209

94 University Avenue

Queen's University

Kingston, Ontario, K7L 3N6

warmanc@econ.queensu.ca 


\section{Introduction}

Wage and cost-of-living levels vary significantly across Canadian cities and provinces, despite the fact that capital and labor are largely mobile within Canada's borders. Coulombe and Lee (1995) and Coulombe (2000) find that income and price levels converged significantly between 1960 and 1980, but have converged relatively little since then. These persistent differences in wages and prices are most naturally explained by persistent differences in local advantages to households and firms, broadly termed as "amenities." To clarify terminology, we say consumption amenities determine an area's overall quality of life (QOL), while production amenities determine an area's overall productivity. The primary goal of this paper is to identify the overall differences in quality-of-life and productivity levels across Canadian cities.

Some places in Canada have undeniable advantages over others. Most Canadians live south, close to the United States border, where the climate is warmer and trading costs are lower than further north. Canadians are acutely aware of regional disparities in natural resource wealth, from oil in Alberta, forests in British Columbia, to depleted fish stocks in the Atlantic provinces. Much of the population is concentrated in a handful of large cities, which benefit from sizable agglomeration economies and vast cultural opportunities, but also suffer disproportionately from urban disamenities such as crime, pollution, and congestion. Strong local and provincial governments, as well as differential treatment of regions by the federal government, also lead to geographic differences in public services and taxation.

While some places appear more advantaged than others, much of the population is still located in less advantaged areas. Although heterogeneity in household tastes and production technologies may help explain this, the importance of heterogeneity should not be overstated: most individuals prefer temperatures above -40 , and most firms benefit from low transportation costs. Furthermore, many Canadians are quite mobile over their lifetime and have only limited local attachments (e.g. Bernard et al. 2008).

In this setting, households and firms in areas with less advantageous amenities should be largely compensated by more advantageous local prices. Specifically, households in areas with lower QOL should be compensated either through higher nominal wages or lower costs-of-living. Firms in less productive areas should be compensated through either lower labor or non-labor costs. This is the essence of the methodology of Rosen (1979) and Roback (1982), which has been used extensively by researchers to measure QOL and 
productivity differences in the United States (e.g. Blomquist et al. 1988, Beeson and Eberts 1989; Gyourko and Tracy 1991; Gabriel and Rosenthal 2004; Shapiro 2006; Chen and Rosenthal 2008).

Surprisingly, this popular methodology has never been applied to Canadian data. We explain this theory in Section 2, using the framework by Albouy (2008a, 2009b), which realistically incorporates federal taxes and produced non-tradable goods, such as housing, in a manner that Roback (1982) suggested, but never implemented. In Section 3, we explain how we calibrate this model for Canada, and use the 2006 Census microdata to estimate wage and housing-cost differences across Census Metropolitan Areas (CMAs), so as to infer QOL and productivity differences across CMAs.

Several issues arise in applying the Rosen-Roback framework to Canada. First, while most areas of Canada are mainly English-speaking, areas such as Quebec, are predominantly French-speaking, while areas such as New Brunswick, are largely bilingual. Different language groups naturally have preferences for different areas, as most would prefer to live where their mother tongue is predominant. Roback (1988) and Beeson (1991) estimate QOL advantages for different groups defined by education groups; we estimate QOL for groups defined by mother tongue, a more pre-determined characteristic. We also discuss, for what appears to be the first time, how the model may be aggregated across types, and be used to estimate productivity differences across groups.

Second, unionization rates in Canada are still high relative to the United States, but vary across regions. This means that some areas may have high real wage levels not because of low amenities, but because of a strong union presence. We find it most plausible to assume that union wage premia do not reflect urban productivity or QOL differences, and use wage estimates purged of unionization effects.

Third, federal and provincial governments play a large role in taxing income and redistributing it through intergovernmental transfers. The role of taxes on residents is dealt with in the model using adjustments in Albouy (2008a; 2009a). It is less clear how the model should accommodate intergovernmental transfers and fiscal disparities due to natural resource wealth, documented in Albouy (2010). Thus, we exclude these from the main analysis, and consider them in alternative results at the end.

According to our estimates in Section 4, the CMA with the highest QOL is Victoria, followed by the BC CMAs of Vancouver, Kelowna, Abbotsford, and then Toronto, Calgary, and Montreal. The rankings for different language groups are almost completely mutually consistent in CMAs with significant quantities of each: Anglophones, Francophones, and Allophones all seem to prefer Montreal to Ottawa-Hull.

Our estimates of the productivity in tradeables, also the first of their kind for Canada, reveal Toronto to 
be the most productive CMA, followed by Calgary, Oshawa, Vancouver, and Ottawa-Hull. While the QOL of Anglophones in Montreal appears to be almost the same as in Toronto, their productivity is lower than that of Anglophones in Kingston. This is consistent with the reasoning in Albouy (2008b) that, since 1970, Anglophones fled Montreal more from a loss of jobs than a loss of amenities.

Under the assumption that there are no sizable differences in unobservable heterogeneity in the productivity of non-tradeables, we create aggregate measures of the value of urban amenities to households and firms, i.e. QOL and productivity in tradeables. According to this metric, the most valuable CMA per hectare is Vancouver, followed by Victoria, Toronto, Calgary, Kelowna, and Montreal. ${ }^{1}$

While QOL greatly interests policy-makers and the general population, published indicators of QOL for Canadian cities consist broadly of weighted sums of arbitrarily chosen amenities, with ad hoc weights. Such indices are found in Cities Ranked \& Rated, Places Rated Almanac, and Mercer's Quality-of-Living Reports. These shed light into what cities people appreciate the most only to the extent that the ad-hoc weighting schemes used in their calculations actually reflect peoples' values. The willingness-to-pay methodology implemented here instead makes use of data on local wages and housing costs to identify the aggregate value of the different amenities. We show in Section 5 that our estimates are generally in line with the popular rankings, but that households put more weight on climate and arts and culture. Finally, in Section 6 we consider how our estimates would be influenced by including intergovernmental transfers, alternative price data from the CPI, or using housing-cost data from rental units alone. ${ }^{2}$

\section{Theoretical Model of Spatial Equilibrium}

Quality-of-life and productivity differences across cities are measured from wage and housing-cost differences across cities using the theoretical framework of Albouy (2008a, 2009a). This framework builds upon that of Rosen (1979) and Roback (1982), but also accounts for non-labor income, housing production,

\footnotetext{
${ }^{1}$ It should be noted that these rankings would change if interprovincial fiscal advantages were efficiently "equalized," as proposed in Albouy (2010): in this case, cities in the Atlantic and Prairie provinces fall in value, while those in Ontario rise.

${ }^{2}$ To our knowledge, the only attempt to measure QOL across Canadian cities in an economic framework, distantly related to the one here, is Giannias (1998), who does so for 13 cities using 1981 data. This work measures QOL according to how housing costs co-vary with six amenity measures, controlling for three housing characteristics, and assuming that incomes do not depend on where households locate. This methodology depends on a highly parametric model with strict normality assumptions and a linear housing price equation, which departs from more established log-linear specifications. Our model instead endogenizes wage differences, controls for many worker and housing characteristics, is independent of any set of chosen amenities, and is illustrated through graphs mapping the relationship of wage and housing-cost differences to QOL and productivity differences. Furthermore, our analysis covers all 33 currently defined Census Metropolitan Areas (CMAs), which we sometimes refer to as "cities," as well as the non-metropolitan areas of Canada, organized by province or territory.
} 
cost-of-living differences from non-housing sources, and inequalities in both federal and provincial taxation. Furthermore, we account for multiple household types to allow for language groups, like Roback (1988) and Beeson (1991), but in a richer setting that deals with issues of aggregation and productivity measurement.

\subsection{Setup}

The national economy contains many cities, indexed by $j$, which trade with each other and share several types of mobile households, indexed by $g \in\{1, . ., G\}$. The population in city $j$ is denoted as the vector $\mathbf{N}^{j}=\left(N_{1}^{j}, \ldots, N_{G}^{j}\right)$. Each household consumes a numeraire traded good, $x$, and a group-specific non-traded local good, ${ }^{3} y_{g}$, with local price, $p_{g}^{j}$, which varies by city and type. This accounts for the possibility that households may consume housing in different neighborhoods or goods produced disproportionately by their own type (e.g. Anglophones in Montreal live in certain neighborhoods and are more likely to consume services produced by other Anglophones). In the empirical implementation of the model, the price of local goods for type $g$ is equated with the cost of housing paid by that type. ${ }^{4}$

Firms produce traded and local goods out of land, capital, and labor. Within a city, factors receive the same payment in either sector. Land, $L$, within each city is homogenous and immobile, and is paid a city-specific price $r^{j}$; each city's land supply, $L^{j}(r)$, may depend positively on $r^{j}$, with a finite elasticity $\varepsilon_{L, r}^{j} \in[0 . \infty){ }^{5}$ Capital, $K$, is costlessly mobile across cities, and is paid the price $\bar{\imath}$ everywhere: this price may be set either nationally or internationally, although for simplicity net foreign asset holdings are set to zero. Households of each type $g, N_{g}$, are perfectly mobile within the country, have identical tastes and endowments, and each supplies a single unit of labor. Because households care about local prices and QOL, wages, denoted by the vector $\mathbf{w}^{j}=\left(w_{g}^{j}, \ldots, w_{G}^{j}\right)$, may vary across cities. The national number of worker-households is fixed at $\mathbf{N}^{T O T}=\left(N_{1}^{T O T}, \ldots, N_{G}^{T O T}\right)$, so that the sum of populations across cities $\sum_{j} \mathbf{N}^{j}=\mathbf{N}^{T O T}$. Households of each type own identical diversified portfolios of land and capital, which pay an income $R_{g}$ from land and $I_{g}$ from capital, regardless of the city they live in. Gross income, $m_{g}^{j} \equiv$

\footnotetext{
${ }^{3}$ The productivity differences in non-traded goods may be quite variable. Without separate data on land values across cities, it is nearly impossible to identify them. However, Albouy (2009b) shows that this does not bias the quality-of-life estimates, and has only a minor bias on the trade-productivity estimates for reasonable calibrations.

${ }^{4}$ As shown in Roback (1980), the use of a single traded good may be used to approximate the case of multiple goods. Factor-price equalization, as in the Hecksher-Ohlin model of trade does not occur, because factors are mobile and many cities may specialize in the production of fewer tradable goods than factors. Furthermore, non-housing goods may be considered to be a combination of traded goods and non-housing local goods.

${ }^{5}$ The assumption of homogenous land is used for simplicity, as we do not directly observe land values in any of our datasets. As discussed in Albouy and Lue (2011), land values within CMAs may differ significantly because of local amenities as well as transportation costs. Our estimates may be taken as an average of the value of land within a city. Our QOL estimates implicitly include a penalty for areas with higher transportation costs.
} 
$R_{g}+I_{g}+w_{g}^{j}$, varies across cities only as wages vary. Out of this income households pay a federal income tax of $\tau\left(m_{g}\right)$, which is redistributed in lump-sum transfers by city, $T_{g}^{j}$, which may vary by city. For expositional ease, provincial taxes are discussed in the Appendix.

Cities differ in two types of attributes: quality of life, which raises household utility and is given by the vector $\mathbf{Q}^{j}=\left(Q_{1}^{j}, \ldots, Q_{G}^{j}\right)$, and productivity in the traded-good sector, which varies by factor and is given by the vector $\mathbf{A}^{j}=\left(A_{1}^{j}, \ldots, A_{G}^{j}, A_{L}^{j}, A_{K}^{j}\right)$. These attributes, in turn, depend on a vector of amenities, $\mathbf{Z}^{j}=$ $\left(Z_{1}^{j}, \ldots, Z_{\bar{k}}^{j}\right)$, natural or artificial, according to some unknown functions $\mathbf{Q}^{j}=\widetilde{Q}\left(\mathbf{Z}^{j}\right)$ and $\mathbf{A}^{j}=\widetilde{A}\left(\mathbf{Z}^{j}\right)$. For a consumption amenity, e.g. safety or clement weather, $\partial \widetilde{Q}_{g} / \partial Z_{k}>0$; for a production amenity, e.g. navigable water or agglomeration economies, $\partial \widetilde{A}_{g} / \partial Z_{k}>0$. It is possible that a single amenity affects both productivity and QOL. ${ }^{6}$

Household preferences are modeled by a utility function $U_{g}\left(x, y_{g} ; Q_{g}\right)$, that is quasi-concave over $x$ and $y_{g}$, and increasing in $Q_{g}$. The expenditure function for a worker of type $g$ in city $j$ is $e_{g}\left(p_{g}^{j}, u_{g} ; Q_{g}^{j}\right) \equiv$ $\min _{x, y}\left\{x+p_{g}^{j} y: U_{g}\left(x, y ; Q_{g}^{j}\right) \geq u_{g}\right\} . Q_{g}$ is normalized so that $e_{g}\left(p_{g}^{j}, \bar{u}_{g} ; Q_{g}^{j}\right)=e_{g}\left(p_{g}^{j}, \bar{u}_{g}\right) / Q_{g}^{j}$, where $e_{g}\left(p_{g}^{j}, \bar{u}_{g}\right) \equiv e_{g}\left(p_{g}^{j}, \bar{u}_{g} ; 1\right)$, meaning that one-percent increase in $Q_{g}$ is equivalent to a one-percent increase in disposable income. Since households are fully mobile, their utility must be the same across all the cities that they inhabit. Thus, the after-tax income households earn in each city should equal the expenditure needed to obtain the common level of utility, $\bar{u}_{g}$, given local prices and QOL: ${ }^{7}$

$$
e_{g}\left(p_{g}^{j}, \bar{u}_{g} ; Q_{g}^{j}\right)=m_{g}^{j}-\tau\left(m_{g}^{j}\right)+T_{g}^{j}
$$

for all types $g$ and cities $j$ where $N_{g}^{j}>0$.

All input and goods markets are perfectly competitive, and firms produce under constant returns to scale. Let the vector $\mathbf{A}_{N}^{j}=\left(A_{1}^{j}, \ldots, A_{G}^{j}\right)$ denote labor productivity, the vector $\mathbf{N}_{X}^{j}=\left(N_{1 X}^{j}, \ldots N_{G X}^{j}\right)$ denote labor used to produce the traded good, and $\mathbf{N}_{Y g}^{j}=\left(N_{Y g 1}^{j}, \ldots, N_{Y g G}^{j}\right)$ denote the labor used to produce each local good $g$, with $\mathbf{N}_{Y}^{j}=\sum_{g} \mathbf{N}_{Y g}^{j}$; similar notation is used for land and capital, with $L_{Y}^{j}=\sum_{g} L_{Y g}^{j}$, etc. Then the production functions of representative traded-good and local-good firms are $X^{j}=F_{X}\left(\mathbf{A}_{N}^{j}\right.$.

\footnotetext{
${ }^{6}$ It is worth noting that amenities may be endogenous to quantities in the model, and that this poses different problems when measuring values by using comparative statics. For example, an increase in population, $N^{j}$, may lead to greater pollution, lowering $Q^{j}$. If a city were to receive a theme-park, improving $Q$, this would raise $N$, raising pollution, and indirectly decreasing $Q$. The value of the theme-park could be measured empirically by controlling for pollution, although the value when accounting for pollution externalities should not control for pollution. Both direct and indirect effects of amenities have to be taken into account when using comparative statics to determine the causal effect of an amenity on the attributes and prices in a city.

${ }^{7}$ The mobility condition need not apply to all households, but only a sufficiently large subset of mobile marginal households.
} 
$\left.\mathbf{N}_{X}^{j}, A_{L}^{j} L_{X}^{j}, A_{K}^{j} K_{X}^{j}\right)$ and $Y_{g}^{j}=F_{Y g}\left(\mathbf{N}_{Y g}^{j}, L_{Y g}^{j}, K_{Y g}^{j}\right)$, for all $g$, where $F_{X}$ and $F_{Y g}$ are concave and exhibit constant returns to scale. All factors are fully employed: $\mathbf{N}_{X}^{j}+\mathbf{N}_{Y}^{j}=\mathbf{N}^{j}, L_{X}^{j}+L_{Y}^{j}=L^{j}$ and $K_{X}^{j}+K_{Y}^{j}=K^{j}$. Unit cost in the traded-good sector is $c_{X}\left(\mathbf{w}^{j}, r^{j}, \bar{\imath} ; A^{j}\right) \equiv \min _{\mathbf{N}, L, K}\left\{\mathbf{w}^{j} \cdot \mathbf{N}+r^{j} L+\bar{\imath} K\right.$ : $\left.F_{X}\left(\mathbf{A}_{N}^{j} \cdot \mathbf{N}_{X}^{j}, A_{L}^{j} L_{X}^{j}, A_{K}^{j} K_{X}^{j}\right)=1\right\}$. As markets are competitive, firms make zero profits in equilibrium, so that

$$
c_{X}\left(\mathbf{w}^{j}, r^{j}, \bar{\imath} ; A^{j}\right)=1
$$

in all cities $j$. A symmetric definition holds for the unit costs in the local-good sectors, $c_{Y g}$, except that, because of data limitations, we assume uniform productivity for all $g$ and $j$

$$
c_{Y g}\left(\mathbf{w}^{j}, r^{j}, \bar{\imath}\right)=p_{g}^{j}
$$

for all types $g$ and cities $j$ where $N_{g}^{j}>0$.

Scalars with superscripts $j$ refer to city-specific values, while those without superscripts refer to national averages. The share of all income that goes to households of type $g$ is denoted $\mu_{g} \equiv N_{g}^{T O T} m_{g} /\left(\sum_{g^{\prime}} N_{g^{\prime}}^{T O T} m_{g^{\prime}}\right)$, with $\boldsymbol{\mu}=\left(\mu_{1}, \ldots, \mu_{G}\right)$; within a city, the comparable notation is $\boldsymbol{\mu}^{j}=\left(\mu_{1}^{j}, \ldots, \mu_{G}^{j}\right)$. For households, denote the average share of gross expenditures spent on traded goods and local goods as $s_{x g} \equiv x_{g} / m_{g}$ and $s_{y g} \equiv p_{g} y_{g} / m_{g}$; denote the shares of income received from labor, land, and capital income as $s_{w g} \equiv$ $w_{g} / m_{g}, s_{R g} \equiv R_{g} / m_{g}$, and $s_{I g} \equiv I_{g} / m_{g}$. Each share may be put into a vector of the form $\mathbf{s}_{x}=$ $\left(s_{x 1}, \ldots, s_{x G}\right)$. Using averages, it is possible to write the aggregate expenditure shares, $s_{y}=\boldsymbol{\mu} \cdot \mathbf{s}_{y}$, and income shares $s_{w}=\boldsymbol{\mu} \cdot \mathbf{s}_{w}$, and so on. For firms producing traded goods, denote the cost shares of labor, land, and capital as $\theta_{N g} \equiv w_{g} N_{X g} / X, \theta_{L} \equiv r L_{X} / X$, and $\theta_{K} \equiv \bar{\imath} K_{X} / X$, with $\boldsymbol{\theta}_{N}=\left(\theta_{N 1}, \ldots, \theta_{N G}\right)$, and the overall labor-cost share $\theta_{N}=\sum_{g} \theta_{N g}$. Denote similarly-defined cost shares in the local -good sector $\phi_{g N}, \phi_{g L}$, and $\phi_{g K}$, with the cost-share of local -good $g$ from labor type $g^{\prime}$ given by $\phi_{g N g^{\prime}}$, so that $\phi_{g N}=\left(\phi_{g N 1}, \ldots, \phi_{g N G}\right)$.

\subsection{Measuring Quality of Life and Productivity}

We begin by considering the case of where there is only one type of household, and continue with an explanation of multiple types, showing under what assumptions we may aggregate results to reproduce the single-type case. 


\subsubsection{Single Household Type}

To analyze the effect of city attributes on prices we log-linearize the equilibrium conditions (1), (2), and (3) around the national average. Thus, for any variable $z, \hat{z}^{j}=\ln z^{j}-\ln \bar{z} \cong\left(z^{j}-\bar{z}\right) / \bar{z}$, approximates the percent difference in city $j$ of $z$ relative to the geometric average $\bar{z}$, which is the value for a nationally representative city. Log-linearized versions of (1), (2), and (3) describe how prices co-vary with city attributes.

$$
\begin{aligned}
& \hat{Q}^{j}=s_{y} \hat{p}_{j}-s_{w}\left(1-\tau^{\prime}\right) \hat{w}^{j}-d T^{j} / m \\
& \hat{A}^{j}=\theta_{N} \hat{w}^{j}+\theta_{L} \hat{r}^{j} \\
& \hat{p}^{j}=\phi_{N} \hat{w}^{j}+\phi_{L} \hat{r}^{j}
\end{aligned}
$$

These equations are first-order approximations around a nationally-representative city and so the share values are national averages. Equation (4a) measures the QOL differential, $\hat{Q}^{j}$, from how high the cost-ofliving, $s_{y} \hat{p}^{j}$, is relative to after-tax nominal income, $s_{w}\left(1-\tau^{\prime}\right) \hat{w}^{j}$, and transfer differences, expressed as a fraction of income, $d T^{j} / m$. Thus, $\hat{Q}^{j}$ expresses the fraction of income households are willing to pay - or if negative, to accept - to live in city $j$ relative to a city with an average QOL. Equation (4b) measures the productivity differential, $\hat{A}^{j}$, from how high the labor costs, $\theta_{N} \hat{w}^{j}$, and land costs, $\theta_{L} \hat{r}^{j}$, are in traded-good production. It measures the percent cost-savings that firms experience from locating in city $j$ relative to the national average. Equation (4c), constrains the local-good price differential, $\hat{p}^{j}$, to equal the labor-cost differential, $\phi_{N} \hat{w}^{j}$, plus the land-cost differential, $\phi_{L} \hat{r}^{j}$. It is safe to assume that local-goods are more land-intensive and less labor-intensive than traded goods, so that $\phi_{L}>\theta_{L}$ and $\theta_{N}>\phi_{N}$

In practice, wage and local -good price differentials are observable and so QOL differentials are measurable directly from (4a). Land-rents are generally unobserved, making it difficult to measure productivity directly from (4b). However, by assuming that local -good productivity is the same across cities, it is possible to infer both land-rent and productivity differentials using only data on local -good costs and wages

$$
\begin{aligned}
\hat{r}^{j} & =\frac{1}{\phi_{L}}\left(\hat{p}^{j}-\phi_{N} \hat{w}^{j}\right) \\
\hat{A}^{j} & =\frac{\theta_{L}}{\phi_{L}} \hat{p}^{j}+\left(\theta_{N}-\phi_{N} \frac{\theta_{L}}{\phi_{L}}\right) \hat{w}^{j}
\end{aligned}
$$


Land rents are inferred in (5) by subtracting off the labor costs $\phi_{N} \hat{w}_{j}$ from $\hat{p}_{j}$ - which in the case of housing could be interpretable as construction costs - and dividing the remainder by the cost share of land, $\phi_{L}$. The productivity measure in () is based off of nominal wage levels through, $\theta_{N} \hat{w}^{j}$, plus the cost share due to land, inferred through local-good prices. The coefficient $\theta_{L} / \phi_{L}>1$ on reflects how much more local-good prices must be weighted when using them to proxy for land values, while the negative term in parentheses removes the double-counting of labor costs in $\hat{p}$.

The total value of amenity-differences for city $j$ is equal to the QOL differential plus the productivity differential times its share of expenditure

$$
\begin{aligned}
\hat{\Omega}^{j} & =\hat{Q}^{j}+s_{x} \hat{A}^{j} \\
& =\frac{s_{R}}{\phi_{L}} \hat{p}^{j}+\left(\tau^{\prime} s_{w}-\frac{s_{R} \phi_{N}}{\phi_{L}}\right) \hat{w}^{j}-\frac{d T^{j}}{m}
\end{aligned}
$$

The second equality, expressed in terms of observable variables, results from substituting in (4a) and (4b). Collecting terms and using (5), and simplifying, we obtain that the total amenity differential, which expresses the social value of land, is equal to the differential value of private land rents, measured as a percent of income, plus the fiscal externalities in terms of additional federal taxes paid net of federal transfers received.

$$
\hat{\Omega}^{j}=s_{R} \hat{r}^{j}+\tau^{\prime} s_{w} \hat{w}^{j}-d T^{j} / m
$$

It is worth noting that if tradable goods are heterogeneous, a higher level of demand for goods produced disproportionately in city $j$ may be conflated with a higher level of productivity. For instance, if the world price for oil is particularly high, and workers in Calgary are concentrated in the oil industry, then the marginal revenue product of workers in Calgary may be relatively high, even if their marginal physical product is not. Thus $\hat{A}^{j}$ may be interpreted as a combination of both real and pecuniary effects.

Furthermore, cities could also vary in their productivity of local goods. As discussed in Albouy (2009b), productivity in local goods cannot be identified without extensive data on land values, which is currently unavailable in Canada. Under our other assumptions, lack of such identification does not affect our measures of quality-of-life, $\hat{Q}^{j}$; the lack does cause our measures of tradable-good productivity, $\hat{A}^{j}$, to be slightly underestimated in cities where local-good productivity is high. Inferred land values both private, $\hat{r}$, and 
social, $\hat{\Omega}^{j}$, are more severely underestimated in such cities, but these are not central to our analysis. ${ }^{8}$

\subsubsection{Multiple Household Types and Aggregation}

With multiple types, the log-linearized version of the mobility condition (1) is

$$
\hat{Q}_{g}^{j}=s_{y g} \hat{p}_{g}^{j}-s_{w g}\left(1-\tau_{g}^{\prime}\right) \hat{w}_{g}^{j}-d T^{j} / m_{g}
$$

for each group $g$. Note that this requires each group's price and wage differentials, $\hat{p}_{g}^{j}$ and $\hat{w}_{g}^{j}$, but also each group's specific marginal tax rate, $\tau_{g}^{\prime}$, expenditure share $s_{y g}$ and income share $s_{w g}$. It is possible to define an aggregate quality-of-life index $\hat{Q}^{j} \equiv \boldsymbol{\mu}^{j} \cdot \hat{\mathbf{Q}}^{j}$ that is consistent with the single-type index in (4a) if we define the aggregate local -good price differential as $\hat{p}^{j} \equiv\left(1 / s_{y}\right) \sum_{g} \mu_{g}^{j} s_{y g} \hat{p}_{g}^{j}$, the aggregate wage as differential as $\hat{w}^{j} \equiv\left(1 / s_{w}\right) \sum_{g} \mu_{g}^{j} s_{w g} \hat{w}_{g}^{j}$, and assume that all groups face the same marginal tax rate $\tau^{\prime}$.

With multiple labor types, the zero-profit condition for tradable-good producing firms is $\hat{A}^{j}=\boldsymbol{\theta}_{N}$. $\hat{\mathbf{w}}^{j}+\theta_{L} \hat{r}^{j}$, where $\hat{A}^{j} \equiv \boldsymbol{\theta}_{N} \cdot \hat{\mathbf{A}}_{N}^{j}+\theta_{L} \hat{A}_{L}^{j}+\theta_{K} \hat{A}_{K}^{j}$ which estimates productivity using the labor-cost measure with $\boldsymbol{\theta}_{N}^{j} \cdot \hat{\mathbf{w}}^{j}$. A potential problem with this approximation is that the local cost shares, $\boldsymbol{\theta}_{N}^{j}$, may vary considerably from the national ones, $\boldsymbol{\theta}_{N}$. But, when each group $g$ 's fraction of total labor costs in city $j, \theta_{N g}^{j} / \theta_{N}$, is proportional to its share of total labor income in city $j$, i.e.,

$$
\frac{\theta_{N g}^{j}}{\theta_{N}}=\mu_{g}^{j} \frac{s_{w g}}{s_{w}} \quad \text { for all } g
$$

the single wage measure proposed above, $\hat{w}^{j}$, reflects labor costs with local cost shares, $\boldsymbol{\theta}_{N}^{j}$, so that $\theta_{N} \hat{w}^{j}=$ $\boldsymbol{\theta}_{N}^{j} \cdot \hat{\mathbf{w}}^{j}$. Thus, estimates from equation (4b) still measure overall productivity, as before, although they reflect the factors in proportion to how they are used locally, rather than nationally.

In Appendix A.1, we show that using this same assumption it is possible to estimate the land-rent differential using equation (5) from aggregate wage and housing-cost differences, using the approximations $\phi_{L}=\left(s_{R}-s_{x} \theta_{L}\right) / s_{y}$ and $\phi_{N}=\left(s_{w}-s_{x} \theta_{N}\right) / s_{y}$. Thus we can have a feasible estimate of productivity from (6) above that estimates the marginal productivity of land through residential housing. Furthermore, if federal marginal tax rates for groups are the same, then the total value of amenities is still given by (7).

\footnotetext{
${ }^{8}$ Higher productivity in non-tradables tends to lower wages and prices by a relatively small amount, and in the same proportion that trade productivity raises them. More generally, the measure of productivity we use strongly reflects higher levels of tradable productivity and, more weakly, lower levels of non-tradable productivity.
} 
As households are perfectly mobile and each type has homogenous tastes, we should expect households to sort across CMAs according to their tastes for local amenities. The centrifugal forces of household preferences may be countered by centripetal forces in production, if different labor types are imperfectly substitutable. In fact, when labor types are imperfect substitutes, the relative productivity of individual types is not inferrable from wage and price information alone. Such inference also requires information on relative factor usage in the traded sector. Using the labor-demand equations for the traded sector, it is possible to show that the relative demand for labor depends on relative wages and relative productivity levels:

$$
\hat{N}_{1 X}^{j}-\hat{N}_{2 X}^{j}=-\sigma_{12}\left(\hat{w}_{1}^{j}-\hat{w}_{2}^{j}\right)+\left(\sigma_{12}-1\right)\left(\hat{A}_{1}^{j}-\hat{A}_{2}^{j}\right)
$$

where $\sigma_{12}$ is the elasticity of substitution between type- 1 and type- 2 labor. ${ }^{9}$ Intuitively, this (along with fixed land supplies) produces downward sloping demand for particular labor types. For instance, one can imagine that producers of tradable output in Montreal could find that having a few native English speakers to be very productive for helping to export its products. However, because of provincial laws requiring the use of French in the workplace, these workers would be less productive than comparable native-French speakers if they were employed in equal proportion. Similarly, Allophones may have some idiosyncratic skills that are imperfect substitutes for those possessed by other language groups, much as Ottaviano and Peri (2006) found for immigrants relative to natives in the United States.

As derived in Appendix A.1.2, equation (11) implies that the productivity of one type is

$$
\hat{A}_{2}^{j}=\frac{\theta_{N 1}^{j}}{\theta_{N 1}^{j}+\theta_{N 2}^{j}} \frac{\hat{N}_{2 X}^{j}-\hat{N}_{1 X}^{j}+\sigma_{12}\left(\hat{w}_{2}^{j}-\hat{w}_{1}^{j}\right)}{\sigma_{12}-1}+\hat{A}^{j}
$$

This formula implies that the greater the elasticity of substitution between the two labor types, the more important wage differences are relative to employment differences in reflecting productivity differences. When labor types are strong substitutes, wages must offset the productivity differences of different types: as $\sigma_{12} \rightarrow \infty, \hat{A}_{2}^{j}=\left(\hat{w}_{2}^{j}-\hat{w}_{1}^{j}\right) \theta_{N 1}^{j} /\left(\theta_{N 1}^{j}+\theta_{N 2}^{j}\right)+\hat{A}^{j}$, which in the case where $N_{1}$ and $N_{2}$ are the only two factors is just $\hat{A}_{2}=\hat{w}_{2}$. But when substitution possibilities are more limited, firms are less able to bid up the relative wage of more productive labor, and information on relative factor usage becomes more important.

\footnotetext{
${ }^{9}$ This equation is often seen in the analysis of skill-biased technical change (e.g. Violante 2008).
} 


\section{Empirical Implementation}

To apply our model to Canada, we estimate city-specific wage and price differentials using Census microdata for the reference year 2005 and calibrate the cost, income, expenditure, and tax parameters from other sources. ${ }^{10}$

\subsection{Data and the Estimation of Wage and Housing-Cost Differentials}

We estimate wage and housing-cost differentials using the 20 percent sample of Canadian Census data from the 2006 Masterfile Microdata Files. Most of the differentials apply to a Census Metropolitan Area (CMA), which consist of municipalities located around an urban core with a population of at least 100,000. The remaining differentials are for non-CMA areas grouped by province. In total, there are 33 CMAs and 13 non-CMA areas.

\subsubsection{Wage Differentials and Union Adjustments}

The inter-urban wage differentials come from a sample of full-time workers, ages 25 to 55, and control for observable skill differences across workers. Thus, for each language group, determined by the mother tongue of the worker, we regress log wages on CMA-indicators $\left(\nu_{w}^{j}\right)$ and on extensive controls $\left(X_{w}^{i}\right)$ in the equation $\ln w^{i j}=X_{w}^{i} \beta_{w}+\nu_{w}^{j}+\varepsilon_{w}^{i j}{ }^{11}$ The estimated values of $\nu_{w}^{j}$, normalized to have a populationweighted average of zero, are our estimates of the log-wage differentials, $\hat{w}_{g}^{j}$. We interpret them as the causal effect of city characteristics on a worker's wage. Identifying these differentials requires that workers do not sort across cities according to their unobserved skills. ${ }^{12}$ The overall differential for each city, $\hat{w}^{j}$, is equal to the average of the $\hat{w}_{g}^{j}$ for each language group, weighted by the number of workers in each city. ${ }^{13}$

\footnotetext{
${ }^{10}$ The reference year for the earnings is the 2005 calendar year. For housing costs, it is the monthly average over the past 12 months with the reference day of interview being May 16, 2006. For renters, it is the current monthly rent paid.

${ }^{11}$ We include a quartic in potential work experience, highest level education (12 indicators), field of study (17 indicators), occupation (24 indicators), industry (15 indicators), immigrant status interacted with the visible minority status (except for Aboriginal status), years since immigration, citizenship status and bilingualism interacted with mother tongue. These variables are all fully interacted with gender. Appendix B provides greater detail on the covariates and regressions. The estimates of the coefficients of the controls are available in an online appendix.

${ }^{12}$ This assumption may not hold completely: Glaeser and Maré (2001) argue that up to one third of the urban-rural wage gap could be due to selection, suggesting that at least two thirds of wage differentials are valid, although this issue deserves greater investigation. At the same time, it is possible that the estimates could be too small, as some control variables, such as occupation or industry, could depend on where the worker locates.

${ }^{13}$ Note that in practice, some workers live and work in different CMAs. We determine the CMA of a worker by their place of work, so that our productivity estimates are clearly characteristic of the city. The QOL estimates should on the whole be more accurate, since they will represent the wages and costs faced by workers with relatively modest commutes. Regardless, the results are almost identical if we assign wage differentials by place of residence, rather than place of work.
} 
When controlling for location and additional controls, Allophones earn wages 19.7 percent lower than Anglophones while Francophones earn 2.9 percent less. ${ }^{14}$ These differences within CMA's could be due to a variety of reasons, such as school quality or discrimination (Albouy 2008b).

As we document in Appendix Table A3, union coverage rates in Canada are high and differ substantially across CMAs, with coverage rates varying from 23 percent in Calgary to almost 50 percent in Quebec, Sherbrooke, and Thunder Bay. To the extent that wages reflect marginal productivity and unions raise them beyond this competitive rate, it is appropriate to adjust them in order to estimate productivity levels. It is theoretically ambiguous whether union wage premia should be discounted when estimating QOL. If union jobs are readily accessible to new migrants, and these higher premia are reflected in higher rents and other costs-of-living, then it would be inappropriate to discount the premia. However, if workers union wage premia do not result in higher local costs-of-living, then it is sensible to discount them. Otherwise, real incomes in highly unionized areas may be high relative to the local QOL, and QOL estimates in highly unionized areas will be biased downwards.

Unfortunately the Census data does not contain information on union coverage. We were able to calculate CMA-level unionization rates from the Labour Force Survey, although these rates are not available by mother tongue. We eliminate inferred union-wage premia by multiplying the union coverage rates by a premium of 7.7 log points, taken from Fang and Verma (2002), and subtracting them from the original estimates of $\hat{w}^{j}$, renormalizing them to have a population-weighted average value of zero.

The importance of the public sector varies greatly by cities. For example, a little less than 40 percent of workers are employed in the public sector in Ottawa compared to less than 15 percent in Toronto. Like unionization, this potentially has an impact on wages. To control for this, we account for the percentage of the workforce in each CMA that works in a public sector job. ${ }^{15}$

\footnotetext{
${ }^{14}$ Although these differentials control for what official languages the worker speaks, the Census does not indicate how proficient respondents are in their languages. It seems likely that self-reported bilingual Anglophones speak English better than self-reported bilingual Francophones do, and vice versa.

${ }^{15} \mathrm{We}$ also imposed the restriction that $\beta_{w}$ is constant across cities. In analyses that we do not report, we did find evidence that there are some differences in the returns to characteristics across cities. For instance, university-educated workers receive less of a premium for working in Vancouver than high-school-educated workers. This suggests that the former enjoy a higher quality-of-life in Vancouver. While interesting, most of these return differences are relatively minor, and for the sake of simplicity, are left for future work.
} 


\subsubsection{Housing-Cost Differentials}

Following previous studies (e.g. Gabriel and Rosenthal 2004), we use both housing values and gross rents, including utilities, to calculate housing-cost differentials. For owned units, we multiply housing values times a discount rate of 7.85 percent (Peiser and Smith 1985), and add utility costs, to impute rents comparable to gross rents. We regress the logarithm of these rents on flexible controls $\left(X_{w}^{i}\right)$ in the equation $\ln p^{i j}=$ $X_{p}^{i} \beta_{p}+\nu_{p}^{j}+\varepsilon_{p}^{i j}{ }^{16}$ The coefficients $\nu_{p}^{j}$, normalized to have a population-weighted average of zero, are our estimates of the housing-cost differentials, $\hat{p}^{j}$. Proper identification of housing-cost differences requires that average unobserved housing quality, and the extent of foreign investment, do not vary systematically across cities. ${ }^{17}$

Controlling for CMA and additional controls, we find that Allophones have housing costs that are almost identical to Anglophones, while Francophones have housing costs that are 15 percent lower. The lower housing costs of Francophones potentially reflect that Anglophones may live in more amenable areas within CMAs, such in Montreal, where historic Anglophone neighborhoods are generally considered very amenable. It may be that Anglophones face a more restricted housing market or enjoy better housing quality that we cannot control for.

\subsection{Calibration}

The calibrated values for the parameters are similar to those for the United States found in Albouy (2009b), except that we amend them for Canada to account for a smaller share of income received by labor, and a smaller proportion of expenditures spent on locally-produced goods.

$$
\begin{array}{llll}
s_{x}=0.67 & \theta_{L}=0.025 & \phi_{L}=0.25 & s_{R}=0.10 \\
s_{y}=0.33 & \theta_{N}=0.775 & \phi_{N}=0.55 & s_{w}=0.70 \\
& \theta_{K}=0.20 & \phi_{K}=0.20 & s_{I}=0.20
\end{array}
$$

\footnotetext{
${ }^{16}$ The controls, which are interacted with renter-status, include number of rooms (9 indicators), number of bedrooms (5 indicators), number of rooms interacted with number of bedrooms, number of rooms per household member, type of building ( 7 indicators), age of building (9 indicators), and state of repair (2 indicators). For owner-occupied units, we include an indicator for condominium status and interact the controls with mortgage status. See Appendix B for more detail. The estimates of the coefficients of the controls are available in an online appendix.

${ }^{17}$ Unobserved housing quality differences should be minor, as Malpezzi et. al. (1998) determine that housing-cost indices derived from the U.S. Census in this way perform as well or better than most other indices. As well, in the admittedly limited data available, foreign investments in major Canadian housing markets appear to be small. For instance, Tal (2011) uses Landcor data, a comprehensive database on historical sales and current information on the $\mathrm{BC}$ residential and commercial markets, to document that only $2.6 \%$ of all sales over the past five years can be accounted by owners whose tax notice is sent to addresses outside of Canada.
} 
Information on income and expenditure share differences by language group is lacking, and so we assume they are the same, which allows us to use equation (10) for our estimates.

The elasticity of substitution between different labor types is unknown. Ottaviano and Peri (2006) estimate the elasticity of substitution between immigrants and non-immigrant workers to be about 6.5. It would seem that the elasticity of substitution between workers of different language groups is much higher than this elasticity, given that the workers were often born and raised in Canada, and thus have even more similar skills. ${ }^{18}$ Thus, we use two potential values for $\sigma: \infty$ and 40 , where the latter illustrates the case of imperfect substitutability.

Although federal tax differences are included in the analysis, federal transfer and spending differences are not. There are three ways that these spending differences could manifest themselves. To the extent that they benefit households, they contribute to $\hat{Q}^{j}$; to the extent that they benefit firms, they contribute to $\hat{A}^{j}$; to the extent that they are wasted by governments, they show up nowhere. Since it is not theoretically clear where they belong, they are reported separately in Section 6.1.

Calculated tax differentials depend on both federal and provincial tax rates. They include direct taxes on income as well as indirect taxes on consumption: since this is a static model without an intertemporal savings decision, the two are equivalent as taxes on consumption reduce the buying power of labor. We determine provincial differentials using wage differences within province only. Across provinces, the average marginal tax rate on labor income is 28 percent. See the Appendix for more details. ${ }^{19}$

\section{Quality-of-Life and Productivity Estimates}

\subsection{Main Estimates}

Columns 2 and 3 of Table 1 report the estimated wage and housing-cost differentials by CMA or nonCMA areas of provinces. Figure 1 graphs these and provides intuition for how we infer overall QOL and productivity differentials, reported in columns 4 and 5 . The figure displays the average mobility condition from (4a), with $\hat{Q}^{j}=0$, and the combined average zero-profit conditions from (6), with $\hat{A}^{j}=0$. The average mobility condition illustrates the housing costs households are willing to pay, on average, for a given

\footnotetext{
${ }^{18}$ We include immigrant controls to capture differences in immigrant/Canadian born earning outcomes. See the Appendix for more detail.

${ }^{19}$ Many workers report receiving little income other than labor income. However, given the static nature of the model, a worker's choices should be modeled to account for a worker's permanent income, which includes a large non-labor component, particularly if implicit rental earnings from one's own home are included.
} 
wage: any premium above that housing cost level is inferred to be payment for consumption amenities, and thus the vertical distance from that condition indicates overall QOL, $\hat{Q}^{j}$. The combined zero-profit condition illustrates the rate at which land rents, inferred through housing costs, must fall, on average, as wages rise: any premium over this is inferred to be payment for production amenities, and thus the vertical (or horizontal) distance from that condition indicates overall firm productivity in the traded sector, $\hat{A}^{j}$. Through a change in the coordinate system, the two conditions in Figure 1 provide a set of axes for the new coordinate system in Figure 2, which is in the space of productivity and QOL.

Interestingly, Canada's five largest CMA's - Toronto, Montreal, Vancouver, Ottawa-Hull, and Calgary, all have above-average productivity and QOL, as they lie above the average mobility-condition, and to the right of the average zero-profit condition. The smaller cities of Halifax, and Kelowna all have aboveaverage QOL but much lower productivity, which is commensurate with their reputations as charming tourist destinations. Kitchener, Oshawa, and Windsor have less-than-average QOL, but are quite productive given their size, although this is likely to do with their proximity to Toronto and Detroit. Also in this category are the Territories, where high wages simultaneously reflect the high marginal productivity of the workers out there, as well as the need for those workers to be compensated for the harsh climate and remote location. Finally, a large number of smaller cities, including

Moncton, Regina, St. John's, Thunder Bay, and Trois-Rivières fall in the category of cities with belowaverage productivity and QOL, with the compensating benefit of being affordable. All of the non-CMA areas of provinces (except for BC) also fall in this category, suggesting that on average neither firms nor households find less urban areas to be exceptionally attractive.

The rankings of the cities in terms of overall QOL, productivity, and combined value are given in Table 2. Victoria has the highest QOL, followed by Vancouver, Kelowna, Abbotsford, and Toronto. Rounding out the top ten are Calgary, Montreal, Sherbrooke, Ottawa-Hull, and Barrie. Saint John, Windsor, and Thunder Bay take the bottom three spots. This list contrasts significantly with Giannias (1998), which places Edmonton and Winnipeg in the top 4 of 13 cities, which here are ranked 17 and 24 out of 33.

From the second column of Table 2, we see that Toronto is the leader in productivity, which is not surprising given that it is the largest city, and home of the financial center of Canada. Second is Calgary, only the fifth largest CMA at that time, but with a strong oil and gas industry. Third, is Oshawa, as it is 50 kilometers from Toronto, with a strong base in automobile manufacturing. Vancouver and Ottawa-Hull round out the top five. All of these cities pay a disproportionate share of federal taxes per capita, as seen in 
column 7 of Table 1, as a result of being so productive. Despite being the second largest CMA in Canada, Montreal is only in tenth place, possibly because of its language barrier with the rest of Canada and the United States.

The land-rent and total-value differentials are reported in columns 6 and 8 in Table 1, with their difference caused by the tax differentials in column 7 , and the ranking reported in column 3 of Table 2 . Their calculation is made visually transparent in Figures 1 and 2 through the average iso-rent and iso-value curves: cities above these lines have above-average rents and total values, respectively. From these we see that Victoria has the highest private value of land, although Vancouver has the highest social value, as its higher wage levels lead to greater positive tax externalities for other Canadians.

\subsection{Estimates for Separate Language Groups}

QOL measures broken down by mother tongue are presented in Table 3 for CMAs with at least 100,000 inhabitants with that mother tongue, and where they constitute at least 10 percent of the population. Calculating QOL measures for cities where a smaller number of individuals have a certain mother tongue raises difficult econometric issues. ${ }^{20}$ On the whole, the QOL rankings for the different language groups are almost identical to those pooling everyone together. For instance, all of the groups prefer Montreal over Ottawa-Hull. The only discrepancy is minor: unlike Anglophones, Allophones appear to view Hamilton slightly more favorably than Ottawa-Hull, perhaps because they make up a larger fraction of the population. Francophones do not seem to despise living in linguistically diverse CMAs, as Montreal and Ottawa-Hull are their top two cities, while the worst two are Trois-Rivières and Chicoutimi-Jonquière. Allophones prefer Canada's three largest cities, Vancouver, Toronto, and Montreal, over all other ones, supporting the notion that Allophones will prefer to live in areas with the greatest number of like-tongued speakers.

The individual productivity of different language groups is given in Table 4 for just a few cities where the supply of each group is large enough to produce credible estimates. Panel A considers the productivity differences between Francophones and Anglophones in Montreal and Ottawa-Hull. In Montreal, average productivity is 3 percent above the national average, and Francophones are better paid and much more heavily employed than Anglophones. If both types of workers are perfect substitutes, then Francophones from

\footnotetext{
${ }^{20}$ In places where a linguistic group is in a small minority, the calculated wage differentials tend to be relatively low and the housing-cost differentials between language groups relatively high. This would seem to suggest that these groups find places where the mother tongue are very amenable. See Warman (2007) for Canadian analysis and evidence of enclaves. It is likely that these individuals have idiosyncratic attachments, such as spouses, that cause them to sacrifice real income in order to live in these places.
} 
Montreal are 4 percent more productive than the average Francophone, while Anglophones are 4 percent less productive, making them about as productive as Anglophones in Kingston. If Anglophones provide special skills that cannot be easily substituted for by Francophone labor, then the productivity differences are even larger: with an elasticity of substitution of 40, an Anglophone worker in Montreal is only 10 percent less productive, comparable Anglophones in Saskatoon, and wages are as high as they are only because Francophones cannot easily replace them. The results for Ottawa-Hull are much less extreme since their national wage and employment differentials are roughly the same.

Panel B considers the productivity differences between Anglophones and Allophones in Toronto and Vancouver. In both CMAs, Allophones earn less of a premium than Anglophones do, but are hired in a greater proportion, relative to the national average. Thus, the less substitutable Allophone labor is for Anglophone labor, the closer their relative productivity differentials. It appears that Anglophones in Vancouver have productivity levels just behind Calgary and ahead of Oshawa.

\section{Relationship with Popular Rankings and Amenities}

The press abounds with popular rankings of Canadian cities according to many characteristics aimed at capturing "livability." Here, we compare our rankings based on revealed preference with the livability ratings from Places Rated Almanac and Cities Ranked and Rated. The popular measures are not grounded in theory and are largely ad-hoc, they reflect popular perceptions of what characteristics make cities "nice" to live in. Unlike the rankings based on willingness-to-pay, the popular rankings also incorporate low cost-of-living and good job-market opportunities as "amenities". In the hedonic framework above, if these factors are properly weighted, they should make all of the cities offer the same utility, making them equally "livable." In practice, the popular rankings put less weight on cost-of-living and job-market opportunities than the framework suggests. ${ }^{21}$

Table 5 reports the correlation coefficients between the rankings in these reports and the overall QOL ranking shown in Table 1 . The correlations are all strongly positive, with the correlation between the two popular rankings being somewhat stronger than that between either popular ranking and the economic one. These correlations are strong despite the fact that the popular rankings include offsetting cost-of-living and job-market opportunities. The general consistency of the rankings seems to be mutually reinforcing to both

\footnotetext{
${ }^{21}$ For instance, in Places Rated, cost-of-living and employment opportunities, are counted as 2 among 9 amenities, all of which receive equal weight.
} 
the economic and popular measures of QOL.

Table 6 estimates the relationship between the economic QOL estimates and various subindices given to cities by Places Rated Almanac. The overall livability index in the Almanac puts equal weight on all of the estimates. Hedonic estimates based on the economic measures of QOL indicate that only the indices for climate and arts and culture have a significant relationship with households' willingness-to-pay. This holds true whether or not CMAs are weighted by population. With only 24 overlapping CMAs in the sample, this test does have low power; indeed factors related to health, crime, and education may be very important in households' location decisions. But it appears unlikely that Places Rated was correct to assign each sub-index the same coefficient: our economic QOL index suggests that the restriction that all of the subindices should have equal coefficients is strongly rejected by the data. Understandably, Canadians care tremendously about climate, and apparently quite a bit about arts and culture, or other amenities that are correlated with those sub-indexes.

\section{Additional Considerations}

The model presented above has the advantage of requiring limited data, and of being intuitive to graph. Yet, additional considerations should be examined which may affect the estimates, in particular with regards to the role of non-housing costs, differences in non-tax federal fiscal benefits, and the use of rents instead of housing prices. Given that it is not clear whether or not these considerations should be incorporated into the estimation of QOL and productivity differentials, and given that they would also be based on incomplete data, available only at the provincial level, they are presented separately in Table 7 . The preceding results are also summarized at the provincial and regional levels here. ${ }^{22}$

\subsection{Intergovernmental Transfers}

An adjustment for intergovernmental transfers and provincial source-based tax revenues is made in column 9. Recall that if these payments benefit households, they should be subtracted from QOL; if they benefit firms, the should be subtracted from productivity: in either case they should be subtracted from the total value. On the other hand, if these payments benefit neither households nor firms, than they should be ignored altogether. Assuming that the payments do affect the total value in some form, they raise the value

\footnotetext{
${ }^{22}$ CMA-level adjustments for QOL and total value, assuming that federal transfers are passed on directly to households, are presented in Tables A1 and A2.
} 
of Ontario and Quebec, while the Atlantic and the Prairie provinces are seen as less valuable. As analyzed in greater detail in Albouy (2010), this is mainly driven by equalization payments, except for Alberta and Saskatchewan, which receive large fiscal benefits by retaining the revenues from taxes on natural resources, rather than sharing them federally.

\subsection{Non-Housing Costs}

According to intercity estimates of the Consumer Price Index, non-housing cost differences are not always proportional to housing-cost differences, as we assumed above. If non-housing costs in an area are high relative to housing costs, then the cost-of-living measure approximated by housing costs is biased downwards in that area. This causes QOL measures in areas with high non-housing costs to be biased downwards. This may be the case in more remote areas of Canada, such as the Territories, where housing is relatively cheap, but other goods are expensive because of transportation costs. ${ }^{23}$

Unfortunately, only one city per province has detailed CPI information. As a result, we need to assume that provincial cost differences are reflected in the representative CMAs, typically each province's largest. These adjustments, in column 10, suggest that QOL and total values may be underestimated in the Atlantic provinces, especially Newfoundland, and overestimated in Quebec.

\subsection{Housing Rents}

Our main analysis measures housing costs by combining actual rents with imputed rents for owner-occupied units. There may be reason to doubt the accuracy of these imputed rent measures, especially during our time period, as housing prices in some markets rose considerably up until 2006. We construct alternate measures using only rented units, which we plot in Appendix Figure A1 against our main estimates of housing costs. As seen in column 11 of Table 7, rents tend to differ less in value across provinces, although using these measures has a fairly minor effect on the overall rankings.

We believe rent-only measures are less accurate than our main measures. Rental units tend to be more centrally located than owned units, and hence less representative of the overall CMA, especially as the

\footnotetext{
${ }^{23}$ Unfortunately, the intercity CPI estimates do not reliably measure housing costs as they rely on a subsample of new housing generally built on the urban fringe. "The sample of builders for each metropolitan area is determined through the use of local market intelligence and verified against relevant building permit data. Where possible, prices are collected from builders who develop entire subdivisions, usually on large tracts of land." The Census sample is more reliable as it samples all housing. For example in Vancouver, the CPI estimates that housing is only 10 percent over the national average, as opposed to 43 percent according to the Census data.
} 
majority of Canadians own their homes. In addition home-ownership rates are generally higher in larger CMAs. Our main housing-cost measures are less prone to potential bias resulting from sample-selection issues.

\section{Conclusion}

This paper presents the first hedonic estimates of QOL and local productivity differences for Canada, accounting for heterogeneity in mother tongues and unionization rates. These estimates are rather sensible and intuitive, with the QOL measures exhibiting a strong positive correlation with popular rankings. We find Victoria has the greatest quality of life, Toronto has the highest productivity, and Vancouver has the most valuable combination of the two. Among cities that they jointly inhabit, Canada's different language groups appear to largely agree on what cities are more attractive, even when they live in different neighborhoods. Local productivity is largely determined by size, but is also affected by other factors such as predominant language, access to natural resources, and proximity to other large cities.

Overall, our estimates measure how valuable different Canadian cities are, not only in producing the goods that households value, but also in delivering the amenities that households want. Most Canadians seem to prefer the amenities of larger metropolitan areas and are willing to consume fewer goods in order to live in them. Despite Canada's enormous wealth in natural resources, the greatest resource Canadians seem to value in production and consumption is each other.

\section{References}

Albouy, David (2008a) "Are Big Cities Really Bad Places to Live? Improving Quality-of-Life Estimates across Cities.” NBER Working Paper No. 14472. Cambridge, MA.

Albouy, David (2008b) “The Wage Gap between Francophones and Anglophones: A Canadian Perspective, 1970-2000.” Canadian Journal of Economics, 41, pp. 1211-1238.

Albouy, David (2009a) “The Unequal Geographic Burden of Federal Taxation.” Journal of Political Economy, 
Albouy, David (2009b) "What are Cities Worth? Land Rents, Local Productivity, and the Value of Amenities.” NBER Working Paper 14981. Cambridge, MA.

Albouy, David (2010) "Evaluating the Efficiency and Equity of Federal Fiscal Equalization.” NBER Working Paper No. 16144. Cambridge, MA.

Beeson, Patricia E. (1991) "Amenities and Regional Differences in Returns to Worker Characteristics." Journal of Urban Economics, 30, pp. 224-241.

Beeson, Patricia E. and Randall W. Eberts (1989) "Identifying Productivity and Amenity Effects in Interurban Wage Differentials." The Review of Economics and Statistics, 71, pp. 443-452.

Bernard, A., R. Finnie and B. St-Jean (2008) "Interprovincial Mobility and Earnings.” Perspectives on Labour and Income, Statistics Canada.

Blomquist, Glenn C., Mark C. Berger and John P. Hoehn (1988) "New Estimates of Quality of Life in Urban Areas.” American Economic Review, 78(1), pp. 89-107.

Chen, Yu and Stuart Rosenthal (2008) "Local Amenities and Life-Cycle Migration: Do People Move for Jobs or Fun?" Journal of Urban Economics, 64, pp. 519-537.

Coulombe, Serge (2000) "New Evidence of Convergence across Canadian Provinces: the Role of Urbanization.” Regional Studies, 34, pp. 713-25.

Coulombe, Serge and Frank C. Lee (1995) “Convergence across Canadian Provinces, 1961 to 1991.” Canadian Journal of Economics, 28, pp. 886-898.

Fang, Tony and Anil Verma (2002) “Union Wage Premium.” Perspectives on Labour and Income, Statistics Canada.

Gabriel, Stuart, and Stuart Rosenthal (2004) "Quality of the Business Environment Versus Quality of Life: Do Firms and Households Like the Same Cities?" The Review of Economics and Statistics, 86, pp. 438-444. Giannias, Dimitrios A. (1998) “A Quality of Life Based Ranking of Canadian Cities.” Urban Studies, 35, pp. 2241-2251.

Gyourko, Joseph and Joseph Tracy (1991) “The Structure of Local Public Finance and the Quality of Life.” Journal of Political Economy, 99, pp 774-806. 
Ottaviano, Gianmarco and Giovanni Peri (2006) "Rethinking the Effects of Immigration on Wages." UC Davis mimeo.

Peiser, R. B. and L. B. Smith (1985) "Homeownership Returns, Tenure Choice and Inflation.” Real Estate Economics, 13, pp. 343-360.

Roback, Jennifer (1982) "Wages, Rents, and the Quality of Life." Journal of Political Economy, 90, pp. $1257-1278$

Roback, Jennifer (1988) "Wages, Rents, and Amenities: Differences among Workers and Regions." Economic Inquiry, 26, pp. 23-41.

Rosen, Sherwin (1979) “Wages-based Indexes of Urban Quality of Life.” in P. Mieszkowski and M. Straszheim, eds. Current Issues in Urban Economics, Baltimore: John Hopkins Univ. Press.

Shapiro, Jesse (2006) "Smart Cities: Quality of Life, Productivity, and the Growth Effects of Human Capital." The Review of Economics and Statistics, 88, pp. 324-335.

Tal, Benjamin (2011) “Canadian Housing Prices-Beware of the Average." Consumer Watch Canada CIBC July 7, 2011.

Warman, Casey (2007) "Ethnic Enclaves and Immigrant Earnings Growth.” Canadian Journal of Economics, 40, pp. 401-422.

Violante, Giovanni (2008) “Skill-Biased Technical Change.” in Steven Durlauf and Lawrence Blume, eds., New Palgrave Dictionary of Economics, Second Edition. (Palgrave Macmillan) 


\section{Appendix}

\section{A Additional Theoretical Details}

\section{A.1 Multiple Household Types}

\section{A.1.1 Land-Rent Estimate}

With multiple types, the estimate of land rents are over-determined, but the cost-shares are typically unknown:

$$
\hat{r}^{j}=\frac{1}{\phi_{g L}}\left(\hat{p}_{g}^{j}-\phi_{g N} \cdot \hat{\mathbf{w}}^{j}\right)
$$

Instead of trying to estimate land rents directly, we take an indirect approach, using the fact that aggregate value of land rents differences should equal the weighted value of amenities minus federal tax payments, and then substituting in our disaggregated indices:

$$
\begin{aligned}
s_{R} \hat{r}^{j} & =\hat{Q}^{j}+s_{x} \hat{A}_{X}-\tau^{\prime} s_{w} \hat{w}^{j} \\
& =\sum_{g} \mu_{g}^{j}\left[s_{y g} \hat{p}_{g}^{j}-s_{w g} \hat{w}_{g}^{j}\right]+s_{x} \sum_{g} \theta_{N g}^{j} \hat{w}_{g}^{j}+s_{x} \theta_{L} \hat{r}^{j} \\
& =s_{y} \hat{p}^{j}-\sum_{g}\left(\mu_{g}^{j} s_{w g}-s_{x} \theta_{N g}^{j}\right) \hat{w}_{g}^{j}+s_{x} \theta_{L} \hat{r}^{j}
\end{aligned}
$$

Solving again for the land-rent differential,

$$
\hat{r}^{j}=\frac{1}{s_{R}-s_{x} \theta_{L}}\left[s_{y} \hat{p}^{j}-\sum_{g}\left(\mu_{g}^{j} s_{w g}-s_{x} \theta_{N g}^{j}\right) \hat{w}_{g}^{j}\right]
$$

and assuming $\theta_{N g}^{j} / \theta_{N}=\mu_{g}^{j} s_{w g} / s_{w}$

$$
\begin{aligned}
\hat{r}^{j} & =\frac{1}{s_{R}-s_{x} \theta_{L}}\left[s_{y} \hat{p}^{j}-\sum_{g} \mu_{g}^{j}\left(s_{w g}-s_{x} \theta_{N}\right) \hat{w}_{g}^{j}\right] \\
& =\frac{1}{s_{R}-s_{x} \theta_{L}}\left[s_{y} \hat{p}^{j}-\left(s_{w}-s_{x} \theta_{N}\right) \hat{w}_{g}^{j}\right] \\
& =\frac{s_{y}}{s_{R}-s_{x} \theta_{L}}\left[\hat{p}^{j}-\frac{s_{w}-s_{x} \theta_{N}}{s_{y}} \hat{w}^{j}\right] \\
& =\frac{1}{\phi_{L}}\left[\hat{p}^{j}-\phi_{N} \hat{w}^{j}\right]
\end{aligned}
$$

So each type just needs to be weighted by their share of income when producing rent and productivity estimates.

\section{A.1.2 Factor-Specific Productivity Estimates}

Factor-specific productivity differences do have first-order effects on quantities in the model. For example, in the case where partial elasticities of substitution across factors within sectors are equal, the relative 
employment of 1-types relative to 2-types is given by

$$
\hat{N}_{1 X}^{j}-\hat{N}_{2 X}^{j}=-\sigma_{12}\left(\hat{w}_{1}^{j}-\hat{w}_{2}^{j}\right)+\left(\sigma_{12}-1\right)\left(\hat{A}_{1}^{j}-\hat{A}_{2}^{j}\right)
$$

The productivity differential may be split into the two components for the labor types of interest, and all of the other factors:

$$
\hat{A}^{j}=\theta_{N 1}^{j} \hat{A}_{1}^{j}+\theta_{N 2}^{j} \hat{A}_{2}^{j}+\sum_{g=3}^{G} \theta_{N g}^{j} \hat{A}_{g}^{j}+\theta_{L}^{j} \hat{A}_{L}^{j}+\theta_{K}^{j} \hat{A}_{K}^{j}=\theta_{N 1}^{j} \hat{A}_{1}^{j}+\theta_{N 2}^{j} \hat{A}_{2}^{j}+\theta_{-}^{j} \hat{A}_{-}^{j}
$$

then

$$
\begin{aligned}
\hat{A}_{1}^{j} & =\frac{1}{\theta_{N 1}^{j}}\left(\hat{A}^{j}-\theta_{N 2}^{j} \hat{A}_{2}^{j}-\theta_{-}^{j} \hat{A}_{-}^{j}\right) \\
\hat{A}_{1}^{j}-A_{2}^{j} & =\frac{1}{\theta_{N 1}^{j}}\left[\hat{A}^{j}-\left(\theta_{N 1}^{j}+\theta_{N 2}^{j}\right) \hat{A}_{2}^{j}-\theta_{-}^{j} \hat{A}_{-}^{j}\right]
\end{aligned}
$$

Substituting back in

$$
\hat{N}_{1}^{j}-\hat{N}_{2}^{j}=-\sigma_{12}\left(\hat{w}_{1}^{j}-\hat{w}_{2}^{j}\right)+\left(\sigma_{12}-1\right) \frac{1}{\theta_{N 1}^{j}}\left[\hat{A}^{j}-\left(\theta_{N 1}^{j}+\theta_{N 2}^{j}\right) \hat{A}_{2}^{j}-\theta_{-}^{j} \hat{A}_{-}^{j}\right]
$$

which implies

$$
\hat{A}_{2}^{j}=\frac{\theta_{N 1}^{j}}{\theta_{N 1}^{j}+\theta_{N 2}^{j}} \frac{\hat{N}_{1}^{j}-\hat{N}_{2}^{j}+\sigma_{12}\left(\hat{w}_{1}^{j}-\hat{w}_{2}^{j}\right)}{\sigma_{12}-1}+\frac{\hat{A}^{j}-\theta_{-}^{j} \hat{A}_{-}^{j}}{\theta_{N 1}^{j}+\theta_{N 2}^{j}}
$$

We assume that all of the other factors have the same relative productivity levels, i.e. $\hat{A}_{-}^{j}=\hat{A}^{j}$ it follows that

$$
\hat{A}_{2}^{j}=\frac{\theta_{N 1}^{j}}{\theta_{N 1}^{j}+\theta_{N 2}^{j}} \frac{\hat{N}_{2}^{j}-\hat{N}_{1}^{j}+\sigma_{12}\left(\hat{w}_{2}^{j}-\hat{w}_{1}^{j}\right)}{\sigma_{12}-1}+\hat{A}^{j}
$$

It is easy to take the limit $\sigma_{12} \rightarrow \infty$ then $\frac{\theta_{N 1}}{\theta_{N 1}+\theta_{N 2}}\left(\hat{w}_{2}^{j}-\hat{w}_{1}^{j}\right)+\hat{A}^{j}$. When $\sigma_{12}=0$, relatively more productive factors are used less, $\hat{A}_{2}^{j}=\frac{\theta_{N 1}}{\theta_{N 1}+\theta_{N 2}}\left(\hat{N}_{1}^{j}-\hat{N}_{2}^{j}\right)+\hat{A}$

\section{A.2 Provincial and Federal Taxes Combined}

Individual provinces may not only have significant tax rates on income, but also significant wage differences within them. This means that the tax differentials faced by households in different cities consist of two components: a federal component and a provincial component. Let the tax burden be given by two components, a federal $F$ and a provincial, $P: \tau(m)=\tau_{F}(m)+\tau_{P}(m)$. Assuming that federal revenues are distributed evenly across the country, and provincial revenues are distributed even within the province, the federal tax differential is

$$
\frac{d \tau^{j}}{m}=\frac{d \tau_{F}^{j}}{m}+\frac{d \tau_{P}^{j}}{m}=s_{w} \tau_{F}^{\prime} \hat{w}^{j}+s_{w} \tau_{P}^{\prime}\left(\hat{w}^{j}-\hat{w}^{P}\right)=s_{w}\left(\tau_{F}^{\prime}+\tau_{P}^{\prime}\right) \hat{w}^{j}-s_{w} \tau_{P}^{\prime} \hat{w}^{P}
$$

where $\hat{w}^{P}$ is the wage differential of the province on average. At the provincial level, the provincial burden is even and so we may easily calculate

$$
Q^{P}=s_{y} \hat{p}^{P}-\left(1-\tau_{F}^{\prime}\right) \hat{w}^{P}
$$


While for a given city the formula is slightly more complicated.

$$
\hat{Q}^{j}=s_{y} \hat{p}-s_{w}\left[\left(\tau_{F}^{\prime}+\tau_{P}^{\prime}\right) \hat{w}^{j}-\tau_{P}^{\prime} \hat{w}^{P}\right]
$$

\section{B Data and Estimation}

We use Canadian Census data from the 2006 Master Microdata Files to calculate wage and housing-cost differentials. The wage differentials are calculated for workers ages 25 to 55, who report working at least 30 hours a week, 26 weeks a year. The CMA assigned to a worker is determined by their place of work. The wage differential of an CMA is found by regressing log hourly wages on individual covariates and indicators for a worker's CMA, using the coefficients on these CMA indicators. The covariates consist of

- 12 indicators of educational attainment: no degree (default); high school degree; other trade; registered apprentice; college $<1$ years; college 1 to 2 years; college $2+$ years; university certificate; bachelors degree; above bachelor; degree in medicine, dentistry, veterinary medicine or optometry; masters; doctorate;

- a quartic in potential experience (years of school are calculated using the 2001 Master Microdata Files for the highest level of education);

- 17 indicators for major field of study: education (default); arts; humanities; social and behavioural sciences; commerce; bio science; engineering and applied science; health; math and physical science; other; natural resource; protect and transport; law; public administration; technologies; computers; information sciences; transportation;

- 15 indicators of industry (2002 NAICS): agriculture (default); other primary; manufacturing; construction; transportation and storage; communication and utilities; wholesale trade; retail trade; finance, insurance, and real estate; business services; public administration federal; public administration other; education; health and social services; accommodations, food, and beverage services; other services;

- 24 indicators of occupation (2006 NOC-S): senior management (default); other management; professional occupations in business and finance; financial, secretarial and administrative occupations; clerical; sciences; professional health; assist health; social science, government service and religion; teachers and professors; arts, recreation and sports; wholesale trade; retail trade; food; protective services; childcare/home support; sales and service occupations n.e.c.; contractors and supervisors in trades/transportation; construction trades; other trades; transport/equipment; trades helpers; primary industry; machine operators and assemblers in manufacturing including supervisors; laborer manufacturing;

- An indicators for immigrant status, and controls for time since immigration and citizenship status;

- 5 indicators of minority status (Aboriginal, Black, Chinese, South Asian, and other) with the last 4 interacted with immigrant status;

- Indicators for bilingualism interacted with mother tongue - French, English, or other - and for other mother tongue interacted with speaking only French and only English;

All covariates are interacted with gender. 
We first run the regression of log wages on the individual covariates and CMA indicators using censusperson weights. From the regressions a predicted wage is calculated using individual characteristics alone to form a new weight equal to the predicted wage times the census-person weight. The new weights (which have only a small effect) are then used in a second regression, which regresses the residuals from the first regression on mother tongue and CMA indicators. The coefficients on the CMA indicators are taken as the overall wage effect. For the mother-tongue specific wage effects, the residuals from the first regression are regressed on CMA indicators interacted with mother tongue indicators, using the coefficients on these interactions.

Housing-cost differentials are calculated using the logarithm of housing costs, which are either reported gross rents or imputed rents derived from housing values. The differential housing cost of a CMA is calculated in a manner similar to wages, except using a regression of rent on a set of covariates at the unit level. The covariates for the adjusted differential are

- 9 indicators for the number of rooms (1 room (default), 2 rooms, ..., 10 or more rooms), 5 indicators for the number of bedrooms (no bedrooms (default), 1 bedroom, ..., 5 or more bedrooms), number of rooms interacted with number of bedrooms, and the number of rooms per household member;

- 7 indicators for the type of building: single-detached house (default); semi-detached or double house; row house; apartment/flat in a duplex; apartment in a building that has five or more storeys; apartment in a building that has fewer than five storeys; other single-attached house; movable dwelling;

- 9 indicators for when the building was built: built in 1920 or before (default); built during period 1921-1945; built during period 1946-1960; built during period 1961-1970; built during period 19711980; built during period 1981-1985; built during period 1986-1990; built during period 1991-1995; built during period 1996-2000; built during period 2001-2006;

- 2 indicators for the condition of the dwelling: only regular maintenance (default); minor repairs; major repairs;

- an indicator for condominium status (owned units only).

All of the variables are interacted with indicators for rental status and among owner-occupied units, an indicator for the presence of a mortgage. Housing-cost differentials are calculated to a series of regressions similar to the ones above, with the mother tongue of the housing unit determined by the household head.

To calculate the marginal tax rates faced by a nationally representative agent in each of the provinces, we first divide the total population into 17 income groups (from 1-10.000 to 250.000+). We then use Income Statistics (Table 2A, Taxable Returns by Income Class) from Canada Revenue Agency Data to calculate the share of the total population in each of the income groups. Subsequently, we obtain the marginal income tax rate (federal plus provincial) that applies to each income group and each province, using the midpoint of each income group as the income of the group. The marginal tax rates for year 2006 are obtained from Walter Harder.

Non-housing cost data are taken from CANSIM and averaged over 2006. They cover the cities of St. John's, NL; Charlottetown-Summerside, PEI; Halifax, NS; Saint John, NB; Montreal, QC; Ottawa, ON; Toronto, ON; Winnipeg, MB; Regina, SK; Edmonton, AB; and Vancouver, BC. Federal transfer differentials are calculated using the total federal intergovernmental transfers data in 2005-2007 from CANSIM Table 384-0011. CMA level unionization rates are calculated using the 2005 Labour Force Survey Master File. It is the proportion of unionized workers to the number of workers. The fraction of the employment in each CMA that is accounted for by the public sector is also calculated using the 2005 Labour Force Survey Master File." 
TABLE 1: PRICES, ATTRIBUTES, AND VALUES ACROSS CANADIAN CITIES

\begin{tabular}{|c|c|c|c|c|c|c|c|c|}
\hline \multirow[b]{2}{*}{ City/Area Name } & \multirow[b]{2}{*}{$\begin{array}{c}\text { Population } \\
(1)\end{array}$} & \multicolumn{2}{|c|}{ Observed Prices } & \multicolumn{2}{|c|}{ Attribute } & \multicolumn{2}{|c|}{ Value Capitalization } & \multirow[b]{2}{*}{$\begin{array}{c}\text { Total } \\
\text { Value } \\
(8)\end{array}$} \\
\hline & & $\begin{array}{c}\text { Wages } \\
\text { (2) }\end{array}$ & $\begin{array}{l}\text { Housing } \\
\text { Costs } \\
\text { (3) }\end{array}$ & $\begin{array}{c}\text { Quality } \\
\text { of Life } \\
\text { (4) }\end{array}$ & $\begin{array}{l}\text { Product- } \\
\text { ivity } \\
\text { (5) }\end{array}$ & $\begin{array}{c}\text { Land } \\
\text { Rent } \\
(6)\end{array}$ & $\begin{array}{c}\text { Tax } \\
\text { Burden } \\
(7)\end{array}$ & \\
\hline \multicolumn{9}{|l|}{ Panel A: Census Metropolitan Areas } \\
\hline Vancouver & $2,047,650$ & 0.04 & 0.45 & 0.13 & 0.07 & 1.70 & 0.009 & 0.180 \\
\hline Victoria & 320,920 & -0.04 & 0.46 & 0.17 & 0.02 & 1.91 & -0.012 & 0.179 \\
\hline Toronto & $4,966,660$ & 0.10 & 0.29 & 0.05 & 0.10 & 0.93 & 0.022 & 0.115 \\
\hline Calgary & $1,053,840$ & 0.09 & 0.24 & 0.04 & 0.09 & 0.78 & 0.021 & 0.098 \\
\hline Kelowna & 159,490 & -0.07 & 0.24 & 0.11 & -0.03 & 1.09 & -0.018 & 0.091 \\
\hline Montréal & $3,534,850$ & 0.02 & 0.14 & 0.04 & 0.03 & 0.52 & 0.008 & 0.061 \\
\hline Abbotsford & 154,830 & -0.03 & 0.12 & 0.06 & -0.01 & 0.56 & -0.007 & 0.049 \\
\hline Ottawa-Hull & 825,790 & 0.07 & 0.11 & 0.00 & 0.06 & 0.29 & 0.015 & 0.044 \\
\hline Guelph & 125,070 & 0.04 & 0.05 & 0.00 & 0.03 & 0.13 & 0.007 & 0.020 \\
\hline Hamilton & 676,780 & 0.03 & 0.05 & 0.00 & 0.03 & 0.14 & 0.006 & 0.020 \\
\hline Oshawa & 326,890 & 0.11 & 0.02 & -0.04 & 0.08 & -0.16 & 0.028 & 0.012 \\
\hline Edmonton & $1,013,400$ & 0.03 & -0.01 & -0.02 & 0.02 & -0.12 & 0.006 & -0.006 \\
\hline Québec & 701,420 & -0.02 & -0.01 & 0.00 & -0.01 & -0.01 & -0.005 & -0.006 \\
\hline Kitchener & 441,420 & 0.05 & -0.02 & -0.03 & 0.03 & -0.18 & 0.010 & -0.007 \\
\hline Barrie & 174,420 & -0.04 & -0.03 & 0.01 & -0.03 & -0.02 & -0.014 & -0.016 \\
\hline Kingston & 147,230 & -0.05 & -0.04 & 0.00 & -0.04 & -0.07 & -0.015 & -0.023 \\
\hline Sherbrooke & 182,330 & -0.08 & -0.05 & 0.02 & -0.06 & -0.02 & -0.024 & -0.026 \\
\hline Peterborough & 114,580 & -0.06 & -0.05 & 0.01 & -0.05 & -0.09 & -0.018 & -0.027 \\
\hline St. Catharines-Niagara & 381,170 & -0.02 & -0.12 & -0.04 & -0.02 & -0.45 & -0.006 & -0.050 \\
\hline Brantford & 122,420 & -0.03 & -0.13 & -0.03 & -0.03 & -0.45 & -0.009 & -0.054 \\
\hline Halifax & 366,790 & -0.11 & -0.16 & 0.01 & -0.09 & -0.39 & -0.018 & -0.056 \\
\hline London & 447,310 & 0.01 & -0.15 & -0.06 & -0.01 & -0.64 & 0.002 & -0.062 \\
\hline Windsor & 316,170 & 0.09 & -0.21 & -0.11 & 0.05 & -1.06 & 0.026 & -0.080 \\
\hline Sudbury & 155,990 & 0.03 & -0.23 & -0.09 & 0.00 & -0.96 & 0.006 & -0.090 \\
\hline Trois-Rivières & 138,160 & -0.01 & -0.25 & -0.08 & -0.03 & -0.99 & 0.000 & -0.099 \\
\hline Chicoutimi-Jonquière & 149,440 & 0.01 & -0.28 & -0.09 & -0.02 & -1.13 & 0.006 & -0.106 \\
\hline Winnipeg & 677,500 & -0.08 & -0.29 & -0.05 & -0.09 & -0.99 & -0.014 & -0.114 \\
\hline Saskatoon & 228,080 & -0.10 & -0.30 & -0.05 & -0.10 & -0.98 & -0.018 & -0.117 \\
\hline Regina & 190,790 & -0.04 & -0.34 & -0.09 & -0.06 & -1.26 & -0.001 & -0.127 \\
\hline Moncton & 123,580 & -0.13 & -0.35 & -0.05 & -0.13 & -1.11 & -0.024 & -0.135 \\
\hline Thunder Bay & 120,720 & -0.01 & -0.39 & -0.13 & -0.04 & -1.54 & 0.000 & -0.154 \\
\hline St. John's & 178,170 & -0.13 & -0.44 & -0.09 & -0.13 & -1.50 & -0.025 & -0.175 \\
\hline Saint John & 119,800 & -0.11 & -0.49 & -0.11 & -0.13 & -1.73 & -0.016 & -0.189 \\
\hline \multicolumn{9}{|l|}{ Non-CMA Areas } \\
\hline British Columbia & $1,327,040$ & -0.05 & -0.05 & 0.01 & -0.04 & -0.08 & -0.010 & -0.018 \\
\hline Northwest Territories & 40,770 & 0.19 & -0.06 & -0.12 & 0.13 & -0.66 & 0.038 & -0.028 \\
\hline Yukon & 29,960 & 0.04 & -0.12 & -0.06 & 0.02 & -0.55 & 0.009 & -0.047 \\
\hline Alberta & $1,153,770$ & -0.03 & -0.16 & -0.04 & -0.04 & -0.58 & -0.009 & -0.066 \\
\hline Ontario & $2,530,520$ & -0.06 & -0.20 & -0.04 & -0.06 & -0.68 & -0.016 & -0.084 \\
\hline Québec & $2,386,520$ & -0.08 & -0.29 & -0.06 & -0.09 & -0.99 & -0.021 & -0.120 \\
\hline Prince Edward Island & 133,830 & -0.25 & -0.48 & -0.04 & -0.23 & -1.36 & -0.049 & -0.185 \\
\hline Nunavut & 29,270 & 0.25 & -0.55 & -0.31 & 0.13 & -2.75 & 0.050 & -0.225 \\
\hline New Brunswick & 473,080 & -0.19 & -0.58 & -0.10 & -0.19 & -1.93 & -0.039 & -0.232 \\
\hline Nova Scotia & 532,270 & -0.23 & -0.59 & -0.09 & -0.22 & -1.88 & -0.049 & -0.237 \\
\hline Manitoba & 445,220 & -0.19 & -0.63 & -0.12 & -0.20 & -2.08 & -0.043 & -0.251 \\
\hline Saskatchewan & 529,430 & -0.20 & -0.75 & -0.15 & -0.22 & -2.54 & -0.045 & -0.299 \\
\hline Newfoundland & 320,930 & -0.18 & -0.95 & -0.23 & -0.23 & -3.39 & -0.036 & -0.375 \\
\hline Canada & $30,616,270$ & 0.09 & 0.30 & 0.07 & 0.06 & 0.71 & 0.020 & 0.082 \\
\hline
\end{tabular}

\footnotetext{
Wage and housing cost data are taken from the Census 2006 Masterfiles. Wage differentials are based on the average logarithm of hourly wages for full-time workers ages 25 to 55, controlling for observable skills. Housing cost differentials based on the average logarithm of rents and housing price, controlling for observable housing characteristics. Quality-of-life, productivity, land rent, tax burden, and total value differentials are based off of formulas explained in Section 2.2.1 in the text for the one household-type case. Fuller details on the data are in the Appendix
} 
TABLE 2: CENSUS METROPOLITAN AREA RANKINGS

\begin{tabular}{|c|c|c|c|}
\hline & Q Quality-of-Life Ranking & $\begin{array}{l}\text { Productivity Ranking } \\
\end{array}$ & Total Value Ranking \\
\hline 1 & Victoria & Toronto & Vancouver \\
\hline 2 & Vancouver & Calgary & Victoria \\
\hline 3 & Kelowna & Oshawa & Toronto \\
\hline 4 & Abbotsford & Vancouver & Calgary \\
\hline 5 & Toronto & Ottawa-Hull & Kelowna \\
\hline 6 & Calgary & Windsor & Montréal \\
\hline 7 & Montréal & Guelph & Ottawa-Hull \\
\hline 8 & Sherbrooke & Kitchener & Abbotsford \\
\hline 9 & Ottawa-Hull & Hamilton & Guelph \\
\hline 10 & Barrie & Montréal & Hamilton \\
\hline 11 & Halifax & Edmonton & Oshawa \\
\hline 12 & Peterborough & Victoria & Edmonton \\
\hline 13 & Kingston & Sudbury & Kitchener \\
\hline 14 & Québec & London & Québec \\
\hline 15 & Hamilton & Abbotsford & Barrie \\
\hline 16 & Guelph & Québec & Kingston \\
\hline 17 & Edmonton & St. Catharines-Niagara & Peterborough \\
\hline 18 & Kitchener & Chicoutimi-Jonquière & Sherbrooke \\
\hline 19 & Brantford & Kelowna & St. Catharines-Niagara \\
\hline 20 & St. Catharines-Niagara & Brantford & Brantford \\
\hline 21 & Oshawa & Barrie & Halifax \\
\hline 22 & Saskatoon & Trois-Rivières & London \\
\hline 23 & Moncton & Kingston & Windsor \\
\hline 24 & Winnipeg & Thunder Bay & Sudbury \\
\hline 25 & London & Peterborough & Trois-Rivières \\
\hline 26 & Trois-Rivières & Regina & Chicoutimi-Jonquière \\
\hline 27 & St. John's & Sherbrooke & Winnipeg \\
\hline 28 & Regina & Winnipeg & Saskatoon \\
\hline 29 & Sudbury & Halifax & Regina \\
\hline 30 & Chicoutimi-Jonquière & Saskatoon & Moncton \\
\hline 31 & Saint John & Saint John & Thunder Bay \\
\hline 32 & Windsor & Moncton & St. John's \\
\hline 33 & Thunder Bay & St. John's & Saint John \\
\hline
\end{tabular}

Rankings based off of data in table 1. 
TABLE 3: WAGE, HOUSING-COST, AND QUALITY-OF-LIFE DIFFERENTIALS BY MOTHER TONGUE

\begin{tabular}{|c|c|c|c|c|c|c|}
\hline Rank & Name & Population Size & $\begin{array}{c}\text { Fraction of } \\
\text { Total }\end{array}$ & Wages & $\begin{array}{c}\text { Housing } \\
\text { Cost }\end{array}$ & $\begin{array}{l}\text { Quality-of } \\
\text { Life }\end{array}$ \\
\hline \multicolumn{7}{|c|}{ Panel A: Anglophones } \\
\hline 1 & Victoria & 275,930 & 0.86 & -0.04 & 0.48 & 0.175 \\
\hline 2 & Vancouver & $1,215,480$ & 0.59 & 0.06 & 0.52 & 0.143 \\
\hline 3 & Kelowna & 136,450 & 0.86 & -0.07 & 0.25 & 0.113 \\
\hline 4 & Abbotsford & 111,720 & 0.72 & -0.04 & 0.17 & 0.074 \\
\hline 5 & Toronto & $2,823,580$ & 0.57 & 0.14 & 0.38 & 0.059 \\
\hline 6 & Calgary & 805,620 & 0.76 & 0.10 & 0.28 & 0.049 \\
\hline 7 & Montréal & 448,710 & 0.13 & -0.02 & 0.12 & 0.049 \\
\hline 8 & Ottawa-Hull & 561,760 & 0.51 & 0.07 & 0.14 & 0.014 \\
\hline 9 & Guelph & 101,260 & 0.81 & 0.02 & 0.08 & 0.013 \\
\hline 10 & Hamilton & 521,760 & 0.77 & 0.04 & 0.09 & 0.012 \\
\hline 11 & Barrie & 155,420 & 0.89 & -0.04 & -0.02 & 0.009 \\
\hline 12 & Kingston & 130,340 & 0.89 & -0.05 & -0.04 & 0.006 \\
\hline 13 & Peterborough & 106,690 & 0.93 & -0.06 & -0.05 & 0.006 \\
\hline 14 & Halifax & 338,550 & 0.92 & -0.11 & -0.17 & 0.004 \\
\hline 15 & Edmonton & 795,610 & 0.79 & 0.03 & 0.02 & -0.011 \\
\hline 16 & Kitchener & 337,780 & 0.77 & 0.04 & 0.02 & -0.016 \\
\hline 17 & Brantford & 108,240 & 0.88 & -0.03 & -0.12 & -0.028 \\
\hline 18 & St. Catharines-Niagara & 309,680 & 0.81 & -0.02 & -0.11 & -0.030 \\
\hline 19 & Oshawa & 285,270 & 0.87 & 0.11 & 0.03 & -0.041 \\
\hline 20 & Saskatoon & 198,190 & 0.87 & -0.10 & -0.29 & -0.046 \\
\hline 21 & Winnipeg & 515,180 & 0.76 & -0.08 & -0.27 & -0.047 \\
\hline 22 & London & 366,120 & 0.82 & 0.01 & -0.13 & -0.050 \\
\hline 23 & Regina & 170,940 & 0.90 & -0.04 & -0.33 & -0.082 \\
\hline 24 & St. John's & 174,350 & 0.98 & -0.13 & -0.44 & -0.084 \\
\hline 25 & Sudbury & 101,230 & 0.65 & 0.00 & -0.31 & -0.101 \\
\hline 26 & Windsor & 234,100 & 0.74 & 0.09 & -0.19 & -0.102 \\
\hline 27 & Saint John & 111,370 & 0.93 & -0.12 & -0.51 & -0.105 \\
\hline 28 & Thunder Bay & 101,930 & 0.84 & -0.01 & -0.38 & -0.122 \\
\hline \multicolumn{7}{|c|}{ Panel B: Francophones } \\
\hline 1 & Montréal & $2,359,840$ & 0.67 & 0.06 & 0.21 & 0.045 \\
\hline 2 & Ottawa-Hull & 366,230 & 0.33 & 0.10 & 0.21 & 0.027 \\
\hline 3 & Sherbrooke & 165,740 & 0.91 & -0.08 & -0.03 & 0.020 \\
\hline 4 & Québec & 672,750 & 0.96 & -0.02 & -0.01 & 0.006 \\
\hline 5 & Trois-Rivières & 134,530 & 0.97 & -0.01 & -0.25 & -0.078 \\
\hline 6 & Chicoutimi-Jonquière & 146,680 & 0.98 & 0.01 & -0.28 & -0.093 \\
\hline \multicolumn{7}{|c|}{ Panel C: Allophones } \\
\hline 1 & Vancouver & 806,880 & 0.39 & 0.00 & 0.32 & 0.107 \\
\hline 2 & Toronto & $2,080,620$ & 0.42 & 0.04 & 0.15 & 0.028 \\
\hline 3 & Montréal & 726,300 & 0.21 & -0.10 & -0.13 & 0.008 \\
\hline 4 & Calgary & 231,480 & 0.22 & 0.06 & 0.06 & -0.007 \\
\hline 5 & Hamilton & 144,830 & 0.21 & 0.01 & -0.12 & -0.046 \\
\hline 6 & Ottawa-Hull & 178,380 & 0.16 & 0.05 & -0.09 & -0.052 \\
\hline 7 & Edmonton & 195,240 & 0.19 & 0.01 & -0.18 & -0.066 \\
\hline 8 & Winnipeg & 132,890 & 0.20 & -0.12 & -0.49 & -0.099 \\
\hline
\end{tabular}

Wage and housing-cost differentials are calculated by language group according to the component orthogonal to observable characteristics but related to the CMA indicators interacted with language-group indicators. 
TABLE 4: RELATIVE PRODUCTIVITY OF SPECIFIC MOTHER TONGUES IN SELECTED CITIES

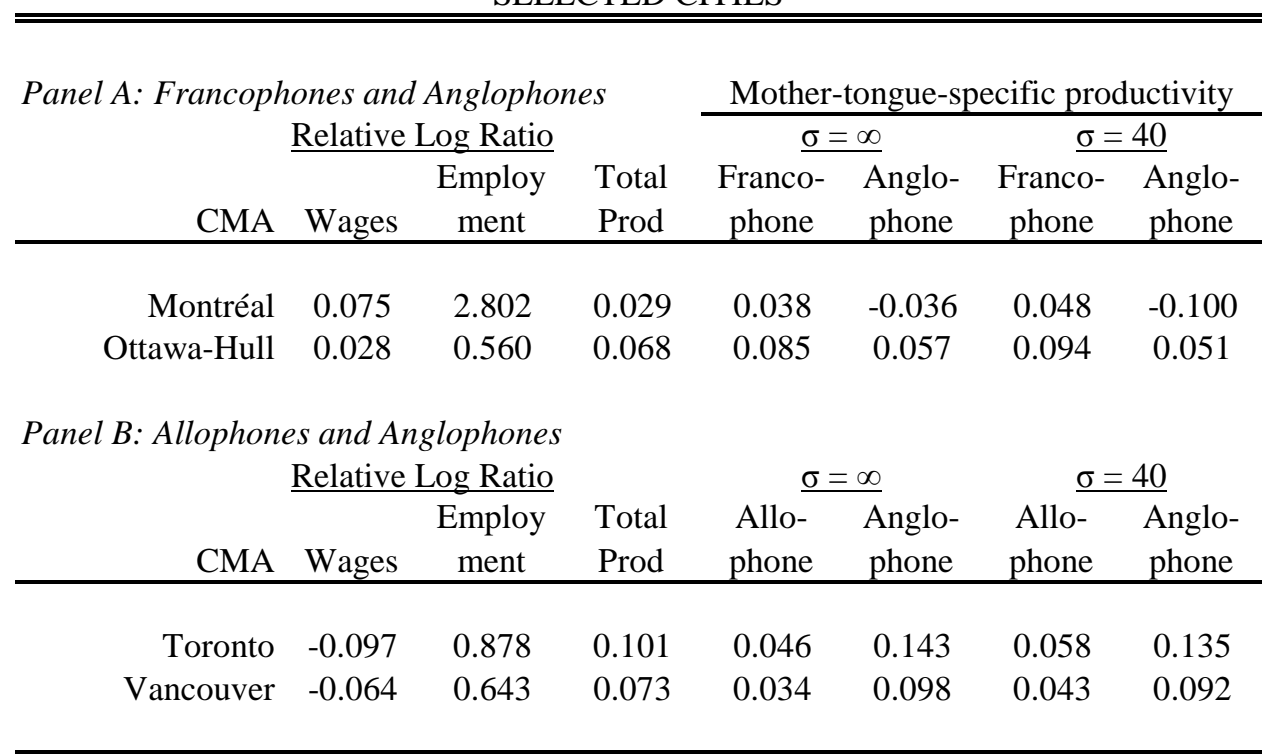

Wage and employment ratios expressed in logarithms relative to the national log ratio (i.e. subtracting the national log ratio). Productivity levels are relative to others in the 
TABLE 5: CORRELATION OF HEDONIC QUALITY-OF-LIFE AND PLACES RATED ALMANAC "LIVABILITY" \& CITIES RANKED AND RATED RANKINGS

\begin{tabular}{rcc}
\hline \hline & $\begin{array}{c}\text { Places Rated } \\
\text { Almanac } \\
(1)\end{array}$ & $\begin{array}{c}\text { Cities Ranked \& } \\
\text { Rated } \\
(2)\end{array}$ \\
\hline Hedonic QOL Rank & 0.70 & 0.72 \\
Places Rated Almanac & & 0.84 \\
\hline
\end{tabular}

TABLE 6: QUALITY OF LIFE, PRODUCTIVITY, AND DISAGGREGATED AMENITIES FROM PLACES RATES

\begin{tabular}{rcc}
\hline \hline & $\begin{array}{c}\text { Quality of Life } \\
\text { (unweighted) } \\
(1)\end{array}$ & $\begin{array}{c}\text { Quality of Life } \\
\text { (pop weight) } \\
(2)\end{array}$ \\
\hline Crts \& Culture & 0.08 & 0.13 \\
& $(0.04)$ & $(0.05)$ \\
Crime & 0.20 & 0.16 \\
& $(0.06)$ & $(0.05)$ \\
Education & 0.05 & 0.04 \\
& $(0.06)$ & $(0.05)$ \\
Recreation & 0.07 & 0.06 \\
& $(0.07)$ & $(0.08)$ \\
Health & -0.01 & -0.03 \\
& $(0.07)$ & $(0.06)$ \\
Transportation & 0.07 & 0.08 \\
& $(0.07)$ & $(0.06)$ \\
Constant & -0.04 & 0.00 \\
& $(0.07)$ & $(0.07)$ \\
& -0.21 & -0.24 \\
& $(0.06)$ & $(0.06)$ \\
Adjusted R-squared & 0.59 & 0.63 \\
Number of Observations & 24 & 24 \\
& & \\
coefficients are equal & 0.005 & 0.007 \\
& & \\
& & \\
& & \\
& & \\
& &
\end{tabular}

Robust standard errors in parentheses. Regressions in the second column are weighted by the sum of individuals in each CMA. 
TABLE 7: PRICES, ATTRIBUTES, AND VALUES ACROSS CANADIAN REGIONS AND PROVINCES WITH ADDITIONAL ADJUSTMENTS

\begin{tabular}{|c|c|c|c|c|c|c|c|c|c|c|c|}
\hline \multirow[b]{2}{*}{ City/Area Name } & \multirow[b]{2}{*}{$\begin{array}{c}\text { Population } \\
(1)\end{array}$} & \multicolumn{2}{|c|}{$\underline{\text { Observed Prices }}$} & \multicolumn{2}{|c|}{ Attribute } & \multicolumn{2}{|c|}{ Value Capitalization } & \multirow[b]{2}{*}{$\begin{array}{c}\text { Total } \\
\text { Value } \\
(8) \\
\end{array}$} & \multicolumn{3}{|c|}{ Adjusted Total Values } \\
\hline & & $\begin{array}{c}\text { Wages } \\
(2) \\
\end{array}$ & $\begin{array}{c}\text { Housing } \\
\text { Costs } \\
\text { (3) }\end{array}$ & $\begin{array}{l}\text { Quality } \\
\text { of Life } \\
(4)\end{array}$ & $\begin{array}{l}\text { Product- } \\
\text { ivity } \\
(5)\end{array}$ & $\begin{array}{c}\text { Land } \\
\text { Rent } \\
(6)\end{array}$ & $\begin{array}{c}\text { Tax } \\
\text { Burden } \\
(7) \\
\end{array}$ & & $\begin{array}{c}\text { Transfer } \\
\text { Differ } \\
(9) \\
\end{array}$ & $\begin{array}{c}\text { Non-Hous } \\
\text { Cost } \\
(10) \\
\end{array}$ & $\begin{array}{c}\text { Housing } \\
\text { Rents } \\
(11) \\
\end{array}$ \\
\hline \multicolumn{12}{|l|}{ Panel A: Provinces } \\
\hline British Columbia & $4,009,930$ & -0.01 & 0.24 & 0.08 & 0.02 & 0.98 & -0.002 & 0.096 & 0.090 & 0.071 & 0.028 \\
\hline Ontario & $11,873,140$ & 0.04 & 0.04 & -0.01 & 0.03 & 0.08 & 0.007 & 0.014 & 0.040 & 0.038 & 0.017 \\
\hline Alberta & $3,221,010$ & 0.03 & 0.02 & -0.01 & 0.02 & 0.01 & 0.005 & 0.006 & -0.069 & 0.001 & 0.009 \\
\hline Northwest Territories & $7,373,310$ & -0.03 & -0.07 & -0.01 & -0.02 & -0.22 & -0.006 & -0.028 & -0.007 & -0.060 & -0.026 \\
\hline Quebec & 40,770 & 0.19 & -0.06 & -0.12 & 0.13 & -0.66 & 0.038 & -0.028 & -0.233 & -0.028 & -0.050 \\
\hline Yukon & 29,960 & 0.04 & -0.12 & -0.06 & 0.02 & -0.56 & 0.009 & -0.047 & -0.235 & -0.047 & -0.036 \\
\hline Nova Scotia & 899,060 & -0.17 & -0.39 & -0.04 & -0.16 & -1.17 & -0.034 & -0.151 & -0.180 & -0.091 & -0.075 \\
\hline Manitoba & $1,122,720$ & -0.12 & -0.41 & -0.08 & -0.13 & -1.37 & -0.024 & -0.161 & -0.200 & -0.139 & -0.104 \\
\hline Prince Edward Island & 133,830 & -0.25 & -0.48 & -0.04 & -0.23 & -1.36 & -0.049 & -0.186 & -0.221 & -0.125 & -0.100 \\
\hline New Brunswick & 716,460 & -0.15 & -0.52 & -0.10 & -0.16 & -1.74 & -0.030 & -0.204 & -0.241 & -0.146 & -0.116 \\
\hline Saskatchewan & 948,300 & -0.13 & -0.53 & -0.11 & -0.15 & -1.81 & -0.027 & -0.208 & -0.265 & -0.160 & -0.115 \\
\hline Nunavut & 29,270 & 0.25 & -0.55 & -0.31 & 0.13 & -2.75 & 0.050 & -0.225 & -0.506 & -0.225 & -0.303 \\
\hline Newfoundland & 499,100 & -0.15 & -0.70 & -0.16 & -0.18 & -2.47 & -0.031 & -0.278 & -0.347 & -0.186 & -0.165 \\
\hline \multicolumn{12}{|l|}{ Panel B: Regions } \\
\hline West & 7,330,940 & 0.01 & 0.12 & 0.04 & 0.02 & 0.47 & 0.002 & 0.049 & 0.006 & 0.038 & 0.017 \\
\hline Central & $19,246,450$ & 0.01 & -0.01 & -0.01 & 0.01 & -0.05 & 0.001 & -0.004 & 0.020 & -0.004 & -0.001 \\
\hline Prairie & $2,071,020$ & -0.13 & -0.47 & -0.09 & -0.14 & -1.60 & -0.026 & -0.185 & -0.233 & -0.150 & -0.109 \\
\hline Atlantic & $2,248,450$ & -0.17 & -0.50 & -0.08 & -0.17 & -1.62 & -0.033 & -0.196 & -0.236 & -0.129 & -0.108 \\
\hline
\end{tabular}

Calculation of differentials in columns 1 through 8 explained in table 1. Transfer differential based on federal integovernmental transfers and province-level source-based revenues, decribed in Albouy (2010). Non-housing cost adjustment based on CPI data for principal city for province. "Housing Rents" uses only housing-cost measures based on rental units, as opposed to all units. 
Figure 1: Housing Costs versus Wage Levels across CMAs, 2006

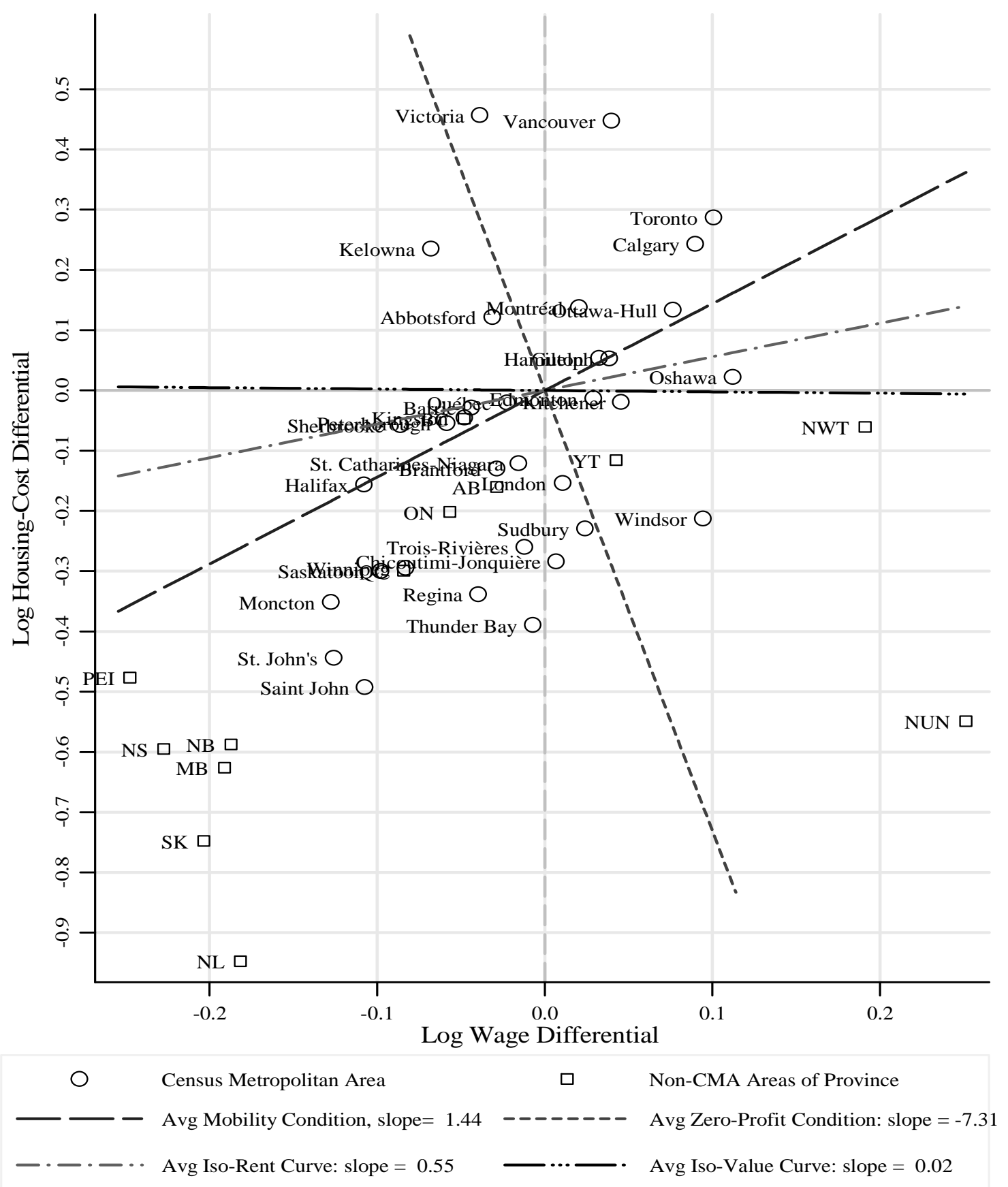




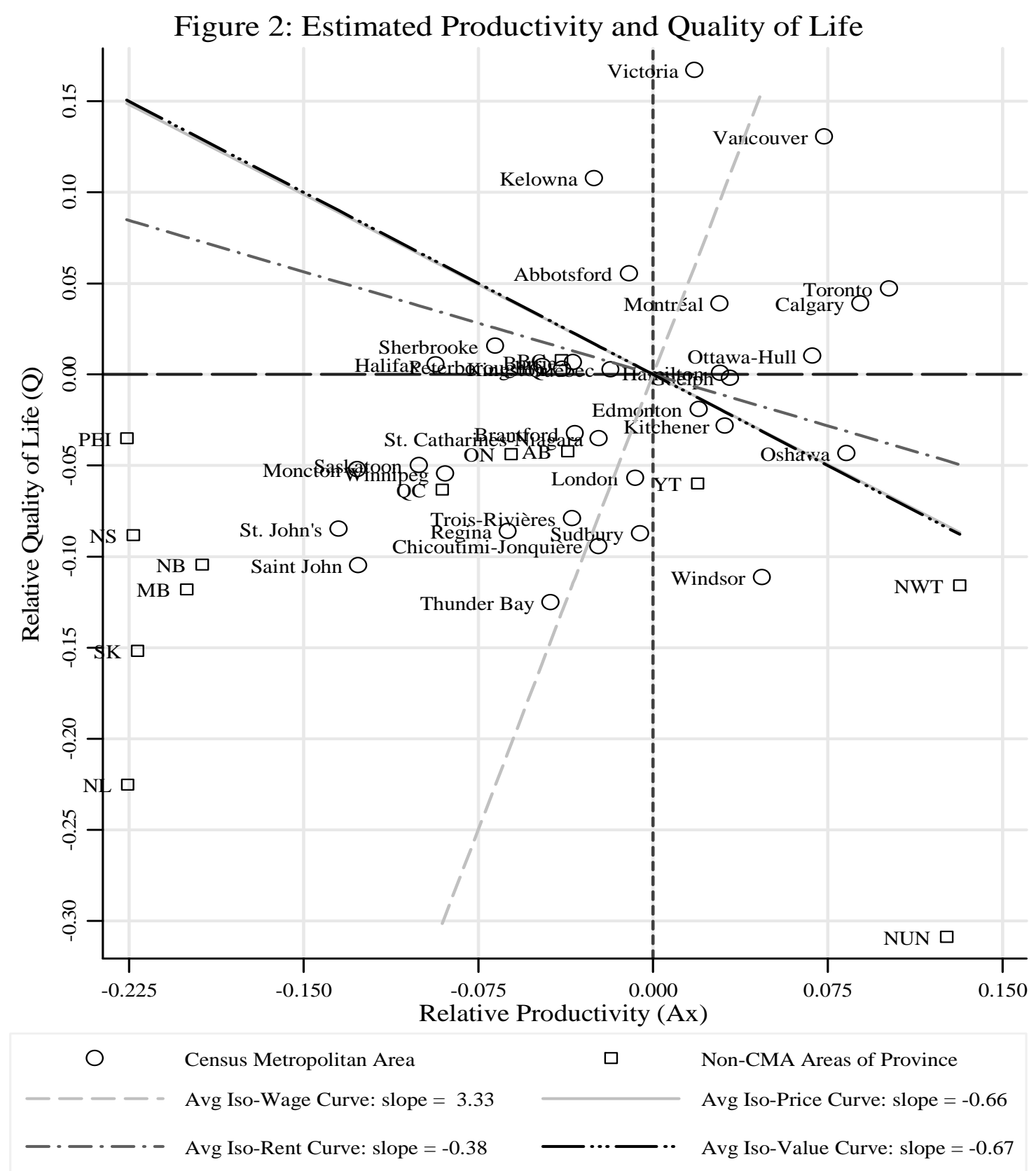


TABLE A1: ALTERNATIVE QUALITY-OF-LIFE MEASURES USING ADJUSTMENTS

\begin{tabular}{|c|c|c|c|c|c|c|c|c|}
\hline & Bas & & \multicolumn{2}{|c|}{ Transfer-adjusted } & \multicolumn{2}{|c|}{ " Non Housing Cost- } & \multicolumn{2}{|c|}{ Rent-adjusted QOL } \\
\hline & $\begin{array}{c}\text { Value } \\
(1)\end{array}$ & $\begin{array}{c}\text { Rank } \\
(2)\end{array}$ & $\begin{array}{c}\text { Value } \\
\text { (3) }\end{array}$ & $\begin{array}{c}\text { Rank } \\
(4)\end{array}$ & $\begin{array}{c}\text { Value } \\
(5)\end{array}$ & $\begin{array}{c}\text { Rank } \\
(6) \\
\end{array}$ & $\begin{array}{c}\text { Value } \\
\text { (7) }\end{array}$ & $\begin{array}{c}\text { Rank } \\
(8) \\
\end{array}$ \\
\hline Victoria & 0.167 & 1 & 0.161 & 1 & 0.113 & 1 & 0.056 & 3 \\
\hline Vancouver & 0.131 & 2 & 0.125 & 2 & 0.078 & 3 & 0.039 & 5 \\
\hline Kelowna & 0.108 & 3 & 0.102 & 3 & 0.083 & 2 & 0.059 & 2 \\
\hline Abbotsford & 0.055 & 4 & 0.050 & 6 & 0.046 & 4 & 0.002 & 15 \\
\hline Toronto & 0.047 & 5 & 0.073 & 4 & 0.038 & 8 & 0.024 & 7 \\
\hline Calgary & 0.039 & 6 & -0.037 & 21 & 0.004 & 14 & -0.003 & 16 \\
\hline Montréal & 0.039 & 7 & 0.060 & 5 & -0.021 & 22 & 0.011 & 13 \\
\hline Sherbrooke & 0.016 & 8 & 0.037 & 7 & -0.018 & 20 & 0.012 & 12 \\
\hline Ottawa-Hull & 0.010 & 9 & 0.035 & 8 & -0.003 & 16 & 0.013 & 11 \\
\hline British Columbia, non-CMA & 0.008 & . & 0.002 & . & 0.021 & . & -0.024 & . \\
\hline Barrie & 0.007 & 10 & 0.033 & 9 & 0.040 & 6 & 0.053 & 4 \\
\hline Halifax & 0.006 & 11 & -0.023 & 19 & 0.035 & 9 & 0.060 & 1 \\
\hline Peterborough & 0.005 & 12 & 0.031 & 10 & 0.041 & 5 & 0.021 & 8 \\
\hline Kingston & 0.003 & 13 & 0.029 & 11 & 0.038 & 7 & 0.021 & 9 \\
\hline Québec & 0.003 & 14 & 0.024 & 14 & -0.036 & 26 & 0.019 & 10 \\
\hline Hamilton & 0.001 & 15 & 0.027 & 12 & 0.023 & 10 & -0.009 & 20 \\
\hline Guelph & -0.002 & 16 & 0.024 & 13 & 0.020 & 11 & -0.004 & 18 \\
\hline Edmonton & -0.019 & 17 & -0.095 & 28 & -0.020 & 21 & -0.006 & 19 \\
\hline Kitchener & -0.028 & 18 & -0.002 & 15 & 0.004 & 15 & -0.012 & 21 \\
\hline Brantford & -0.032 & 19 & -0.006 & 16 & 0.014 & 12 & -0.016 & 24 \\
\hline St. Catharines-Niagara & -0.035 & 20 & -0.009 & 17 & 0.010 & 13 & -0.013 & 22 \\
\hline Prince Edward Island & -0.035 & . & -0.070 & . & 0.025 & . & 0.051 & . \\
\hline Alberta, non-CMA & -0.042 & . & -0.118 & . & -0.024 & . & -0.008 & . \\
\hline Oshawa & -0.043 & 21 & -0.017 & 18 & -0.017 & 19 & -0.022 & 27 \\
\hline Ontario, non-CMA & -0.044 & . & -0.018 & . & 0.012 & . & -0.029 & . \\
\hline Saskatoon & -0.050 & 22 & -0.107 & 30 & -0.032 & 25 & 0.005 & 14 \\
\hline Moncton & -0.052 & 23 & -0.089 & 26 & -0.016 & 18 & 0.035 & 6 \\
\hline Winnipeg & -0.054 & 24 & -0.093 & 27 & -0.047 & 28 & -0.004 & 17 \\
\hline London & -0.057 & 25 & -0.031 & 20 & -0.007 & 17 & -0.021 & 26 \\
\hline Yukon Territory & -0.060 & . & -0.248 & . & -0.060 & . & -0.048 & . \\
\hline Quebec, non-CMA & -0.063 & . & -0.042 & . & -0.065 & . & -0.041 & . \\
\hline Trois-Rivières & -0.079 & 26 & -0.058 & 22 & -0.085 & 32 & -0.045 & 29 \\
\hline St. John's & -0.085 & 27 & -0.154 & 33 & -0.028 & 24 & -0.019 & 25 \\
\hline Regina & -0.086 & 28 & -0.143 & 32 & -0.063 & 31 & -0.013 & 23 \\
\hline Sudbury & -0.087 & 29 & -0.061 & 23 & -0.028 & 23 & -0.049 & 30 \\
\hline Nova Scotia, non-CMA & -0.088 & . & -0.117 & . & -0.001 & . & 0.007 & . \\
\hline Chicoutimi-Jonquière & -0.094 & 30 & -0.073 & 24 & -0.097 & 33 & -0.057 & 31 \\
\hline New Brunswick,non-CMA & -0.104 & . & -0.141 & . & -0.037 & . & -0.004 & . \\
\hline Saint John & -0.105 & 31 & -0.142 & 31 & -0.050 & 29 & -0.040 & 28 \\
\hline Windsor & -0.111 & 32 & -0.085 & 25 & -0.054 & 30 & -0.071 & 33 \\
\hline Northwest Territory & -0.116 & . & -0.321 & . & -0.116 & . & -0.138 & . \\
\hline Manitoba, non-CMA & -0.118 & . & -0.157 & . & -0.067 & . & -0.047 & . \\
\hline Thunder Bay & -0.125 & 33 & -0.099 & 29 & -0.044 & 27 & -0.063 & 32 \\
\hline Saskatchewan, non-CMA & -0.152 & . & -0.209 & . & -0.074 & . & -0.027 & . \\
\hline Newfoundland, non-CMA & -0.225 & . & -0.294 & . & -0.101 & . & -0.068 & . \\
\hline Nunavut Territory & -0.309 & . & -0.590 & . & -0.309 & . & -0.387 & . \\
\hline
\end{tabular}


TABLE A2: ALTERNATIVE TOTAL VALUE MEASURES USING ADJUSTMENTS

\begin{tabular}{|c|c|c|c|c|c|c|c|c|}
\hline & \multicolumn{2}{|c|}{ Base Value } & \multicolumn{2}{|c|}{$\frac{\text { Transfer-adjusted }}{\text { Value }}$} & \multicolumn{2}{|c|}{$\frac{\text { Non Housing Cost- }}{\text { Adjusted Value }}$} & \multicolumn{2}{|c|}{$\underline{\text { Rent-adjusted Value }}$} \\
\hline & $\begin{array}{l}\text { Value } \\
(1)\end{array}$ & $\begin{array}{c}\text { Rank } \\
(2)\end{array}$ & $\begin{array}{l}\text { Value } \\
\text { (3) }\end{array}$ & $\begin{array}{c}\text { Rank } \\
(4)\end{array}$ & $\begin{array}{l}\text { Value } \\
\text { (5) }\end{array}$ & $\begin{array}{c}\text { Rank } \\
(6)\end{array}$ & $\begin{array}{c}\text { Value } \\
\text { (7) }\end{array}$ & $\begin{array}{c}\text { Rank } \\
(8)\end{array}$ \\
\hline Vancouver & 0.180 & 1 & 0.174 & 1 & 0.127 & 1 & 0.088 & 2 \\
\hline Victoria & 0.179 & 2 & 0.173 & 2 & 0.125 & 2 & 0.068 & 3 \\
\hline Toronto & 0.115 & 3 & 0.141 & 3 & 0.106 & 3 & 0.092 & 1 \\
\hline Calgary & 0.098 & 4 & 0.023 & 11 & 0.063 & 5 & 0.056 & 5 \\
\hline Kelowna & 0.091 & 5 & 0.085 & 4 & 0.066 & 4 & 0.042 & 6 \\
\hline Montréal & 0.058 & 6 & 0.079 & 6 & -0.002 & 15 & 0.030 & 9 \\
\hline Ottawa-Hull & 0.056 & 7 & 0.080 & 5 & 0.043 & 6 & 0.059 & 4 \\
\hline Abbotsford & 0.049 & 8 & 0.043 & 9 & 0.039 & 9 & -0.005 & 16 \\
\hline Guelph & 0.020 & 9 & 0.046 & 7 & 0.042 & 7 & 0.018 & 10 \\
\hline Hamilton & 0.020 & 10 & 0.046 & 8 & 0.042 & 8 & 0.010 & 11 \\
\hline Oshawa & 0.012 & 11 & 0.038 & 10 & 0.038 & 10 & 0.033 & 7 \\
\hline Edmonton & -0.006 & 12 & -0.082 & 24 & -0.007 & 17 & 0.007 & 13 \\
\hline Kitchener & -0.008 & 13 & 0.019 & 12 & 0.024 & 11 & 0.009 & 12 \\
\hline Québec & -0.009 & 14 & 0.011 & 13 & -0.048 & 23 & 0.007 & 14 \\
\hline Barrie & -0.016 & 15 & 0.010 & 14 & 0.017 & 12 & 0.030 & 8 \\
\hline British Columbia, non-CMA & -0.018 & . & -0.024 & . & -0.005 & . & -0.050 & . \\
\hline Kingston & -0.023 & 16 & 0.003 & 15 & 0.012 & 13 & -0.005 & 17 \\
\hline Peterborough & -0.027 & 17 & -0.001 & 16 & 0.009 & 14 & -0.010 & 18 \\
\hline Northwest Territory & -0.028 & . & -0.233 & . & -0.028 & . & -0.050 & . \\
\hline Sherbrooke & -0.029 & 18 & -0.009 & 17 & -0.063 & 24 & -0.033 & 21 \\
\hline Yukon Territory & -0.047 & . & -0.235 & . & -0.047 & . & -0.036 & . \\
\hline St. Catharines-Niagara & -0.051 & 19 & -0.024 & 18 & -0.005 & 16 & -0.028 & 20 \\
\hline Brantford & -0.055 & 20 & -0.028 & 19 & -0.008 & 18 & -0.038 & 22 \\
\hline Halifax & -0.057 & 21 & -0.086 & 25 & -0.028 & 21 & -0.002 & 15 \\
\hline London & -0.062 & 22 & -0.036 & 20 & -0.012 & 19 & -0.027 & 19 \\
\hline Alberta, non-CMA & -0.067 & . & -0.142 & . & -0.048 & . & -0.033 & . \\
\hline Windsor & -0.080 & 23 & -0.054 & 21 & -0.023 & 20 & -0.040 & 23 \\
\hline Ontario, non-CMA & -0.084 & . & -0.058 & . & -0.028 & . & -0.070 & . \\
\hline Sudbury & -0.091 & 24 & -0.065 & 22 & -0.031 & 22 & -0.053 & 25 \\
\hline Trois-Rivières & -0.102 & 25 & -0.081 & 23 & -0.109 & 30 & -0.068 & 29 \\
\hline Chicoutimi-Jonquière & -0.110 & 26 & -0.089 & 26 & -0.113 & 31 & -0.073 & 30 \\
\hline Winnipeg & -0.114 & 27 & -0.153 & 28 & -0.107 & 29 & -0.063 & 28 \\
\hline Saskatoon & -0.117 & 28 & -0.174 & 30 & -0.099 & 26 & -0.062 & 27 \\
\hline Quebec, non-CMA & -0.124 & . & -0.103 & . & -0.125 & . & -0.101 & . \\
\hline Regina & -0.128 & 29 & -0.185 & 31 & -0.105 & 28 & -0.055 & 26 \\
\hline Moncton & -0.137 & 30 & -0.174 & 29 & -0.101 & 27 & -0.050 & 24 \\
\hline Thunder Bay & -0.154 & 31 & -0.128 & 27 & -0.073 & 25 & -0.092 & 31 \\
\hline St. John's & -0.175 & 32 & -0.244 & 33 & -0.118 & 32 & -0.109 & 32 \\
\hline Prince Edward Island & -0.186 & . & -0.221 & . & -0.125 & . & -0.100 & . \\
\hline Saint John & -0.189 & 33 & -0.226 & 32 & -0.135 & 33 & -0.125 & 33 \\
\hline Nunavut Territory & -0.225 & . & -0.506 & . & -0.225 & . & -0.303 & . \\
\hline New Brunswick,non-CMA & -0.233 & . & -0.270 & . & -0.166 & . & -0.133 & . \\
\hline Nova Scotia, non-CMA & -0.237 & . & -0.266 & . & -0.150 & . & -0.142 & . \\
\hline Manitoba, non-CMA & -0.251 & . & -0.290 & . & -0.200 & . & -0.180 & . \\
\hline Saskatchewan, non-CMA & -0.299 & . & -0.356 & . & -0.222 & . & -0.174 & . \\
\hline Newfoundland, non-CMA & -0.375 & . & -0.445 & . & -0.251 & . & -0.218 & . \\
\hline
\end{tabular}


TABLE A3: ADDITIONAL STATISTICS BY CMA, 2006

\begin{tabular}{|c|c|c|c|c|}
\hline CMA & $\begin{array}{c}\text { Union Coverage } \\
\text { Rate }\end{array}$ & $\begin{array}{c}\text { Employment } \\
\text { Rate }\end{array}$ & $\begin{array}{l}\text { Fraction who } \\
\text { work in CMA of } \\
\text { residence }\end{array}$ & $\begin{array}{c}\text { Log CPI Non- } \\
\text { Housing }\end{array}$ \\
\hline St. John's & 0.401 & 0.778 & 0.974 & -0.003 \\
\hline Halifax & 0.346 & 0.818 & 0.980 & 0.010 \\
\hline Moncton & 0.310 & 0.845 & 0.943 & -0.014 \\
\hline Saint John & 0.342 & 0.812 & 0.973 & -0.014 \\
\hline Chicoutimi-Jonquière & 0.541 & 0.751 & 0.951 & -0.053 \\
\hline Québec & 0.492 & 0.835 & 0.956 & -0.053 \\
\hline Sherbrooke & 0.499 & 0.789 & 0.885 & -0.053 \\
\hline Trois-Rivières & 0.542 & 0.791 & 0.850 & -0.053 \\
\hline Montréal & 0.377 & 0.788 & 0.975 & -0.053 \\
\hline Ottawa-Hull & 0.454 & 0.825 & 0.984 & 0.037 \\
\hline Kingston & 0.460 & 0.783 & 0.935 & 0.037 \\
\hline Peterborough & 0.430 & 0.841 & 0.834 & 0.037 \\
\hline Oshawa & 0.425 & 0.841 & 0.566 & 0.037 \\
\hline Toronto & 0.239 & 0.813 & 0.979 & 0.037 \\
\hline Hamilton & 0.328 & 0.822 & 0.737 & 0.037 \\
\hline St. Catharines-Niagara & 0.348 & 0.812 & 0.897 & 0.037 \\
\hline Kitchener & 0.296 & 0.843 & 0.848 & 0.037 \\
\hline Brantford & 0.312 & 0.824 & 0.721 & 0.037 \\
\hline Guelph & 0.295 & 0.867 & 0.717 & 0.037 \\
\hline London & 0.333 & 0.827 & 0.936 & 0.037 \\
\hline Windsor & 0.421 & 0.775 & 0.953 & 0.037 \\
\hline Barrie & 0.276 & 0.877 & 0.595 & 0.037 \\
\hline Sudbury & 0.456 & 0.771 & 0.977 & 0.037 \\
\hline Thunder Bay & 0.497 & 0.797 & 0.976 & 0.037 \\
\hline Winnipeg & 0.423 & 0.837 & 0.973 & -0.041 \\
\hline Regina & 0.444 & 0.855 & 0.981 & -0.029 \\
\hline Saskatoon & 0.436 & 0.844 & 0.974 & -0.029 \\
\hline Calgary & 0.228 & 0.847 & 0.982 & -0.004 \\
\hline Edmonton & 0.298 & 0.821 & 0.977 & -0.004 \\
\hline Kelowna & 0.253 & 0.830 & 0.956 & 0.009 \\
\hline Abbotsford & 0.343 & 0.808 & 0.644 & 0.009 \\
\hline Vancouver & 0.340 & 0.792 & 0.986 & 0.009 \\
\hline Victoria & 0.384 & 0.825 & 0.983 & 0.009 \\
\hline NL,non-CMA & 0.438 & 0.619 & & -0.003 \\
\hline PEI & 0.377 & 0.798 & & -0.004 \\
\hline NS,non-CMA & 0.345 & 0.734 & & 0.010 \\
\hline NB,non-CMA & 0.338 & 0.724 & & -0.014 \\
\hline QC,non-CMA & 0.479 & 0.779 & & -0.053 \\
\hline ON,non-CMA & 0.389 & 0.808 & & 0.037 \\
\hline MB,non-CMA & 0.436 & 0.839 & & -0.041 \\
\hline SK,non-CMA & 0.367 & 0.838 & & -0.029 \\
\hline AB,non-CMA & 0.257 & 0.848 & & -0.004 \\
\hline BC,non-CMA & 0.402 & 0.790 & & 0.009 \\
\hline
\end{tabular}


Figure A1: Housing Costs versus Wage Levels across CMAs, 2006

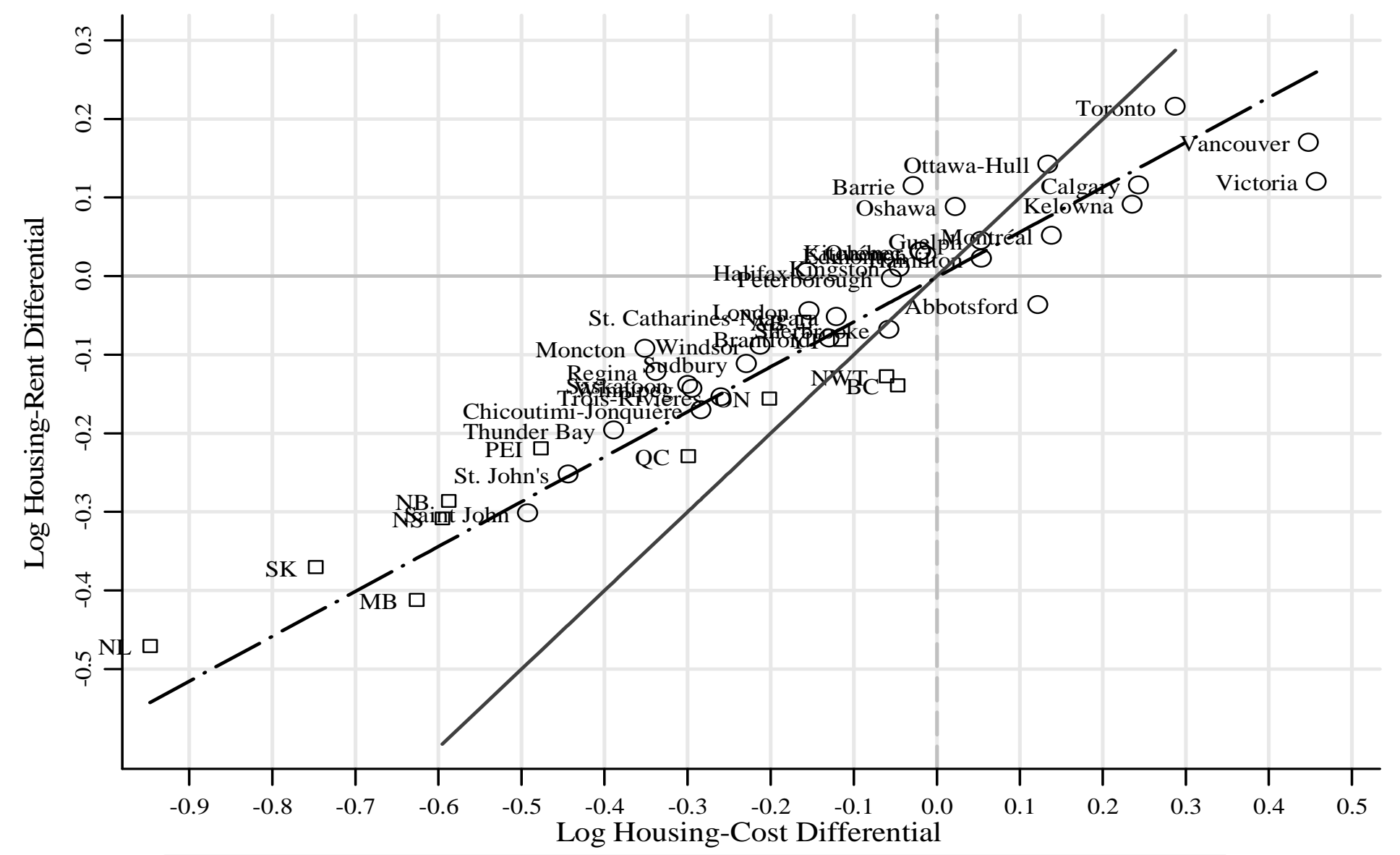

$\bigcirc \quad$ Census Metropolitan Area

$\square \quad$ Non-CMA Areas of Province

Diagonal

$-\cdots--\quad$ Fitted line: slope $=0.57$ 